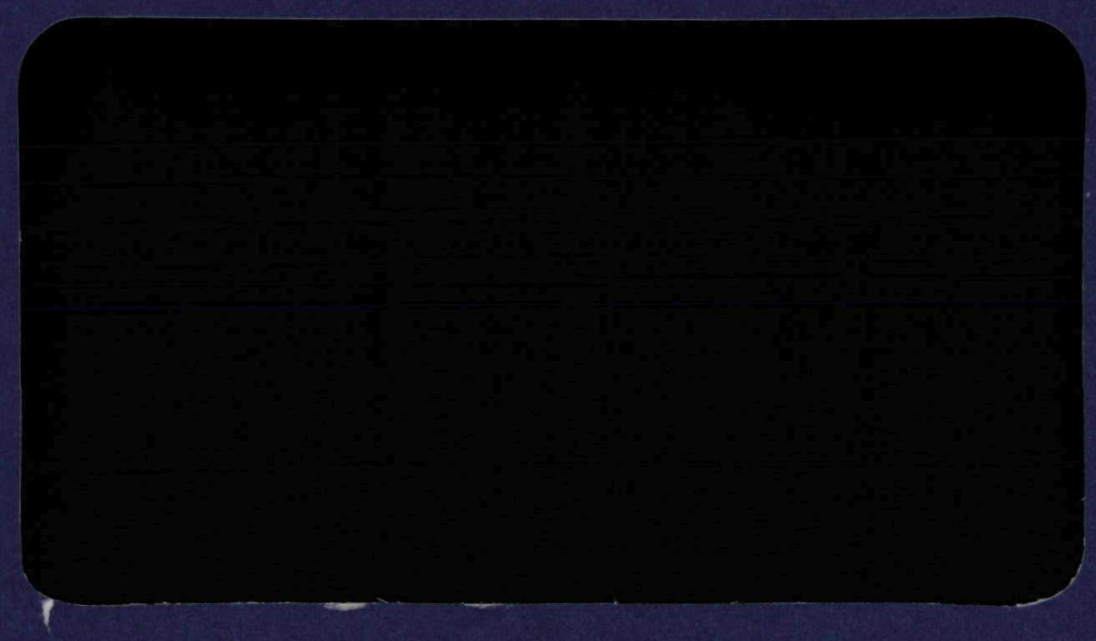

Westinghouse Advanced Reactors Division 


\section{DISCLAIMER}

This report was prepared as an account of work sponsored by an agency of the United States Government. Neither the United States Government nor any agency Thereof, nor any of their employees, makes any warranty, express or implied, or assumes any legal liability or responsibility for the accuracy, completeness, or usefulness of any information, apparatus, product, or process disclosed, or represents that its use would not infringe privately owned rights. Reference herein to any specific commercial product, process, or service by trade name, trademark, manufacturer, or otherwise does not necessarily constitute or imply its endorsement, recommendation, or favoring by the United States Government or any agency thereof. The views and opinions of authors expressed herein do not necessarily state or reflect those of the United States Government or any agency thereof. 


\section{DISCLAIMER}

Portions of this document may be illegible in electronic image products. Images are produced from the best available original document. 


\section{STAINLESS STEEL CLADDING DEVELOPMENT QUARTERLY PROGRESS REPORT}

FOR THE PERIOD ENDING SEPTEMBER 30, 1970

\section{MSTER}

Approved:

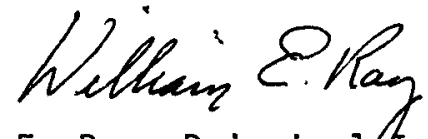

W. E. Ray, Principal Investigator

Approved:

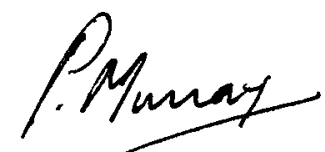

P. Murray $\overbrace{\text { Project Manager }}$

Contract AT (30-1) -4135

U. S. Atomic Energy Commission

Submitted to AEC-NYOO in December 1970

WESTINGHOUSE ELECTRIC CORPORATION

Advanced Reactors Division

P. 0. Box 158 Madison, Pennsylvania 15663 
This report was prepared as an account of work sponsored by the United States Government. Neither the United States nor the United States Atomic Energy Commission, nor any of their employees, nor any of their contractors, subcontractors, or their employees, makes any warranty, express or implied, or assumes any legal liability or responsibility for the accuracy, completeness or usefulness of any information, apparatus, product or process disclosed, or represents that its use would not infringe privately owned rights.

\section{AVAILABILITY NOTICE}

Printed in the United States of America Available from

National Technical Information Service Springfield, Virginia 22151

Price: Printed Copy $\$ 3.00 ;$ Microflche $\$ 0.65$ 
TABLE OF CONTENTS

Section

Page

1

Introduction $\ldots \ldots \ldots \ldots \ldots \ldots \ldots \ldots \ldots \ldots \ldots \ldots \ldots \ldots$

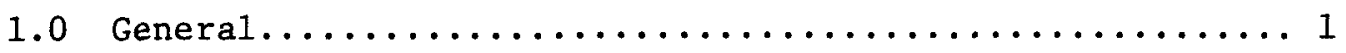

2.0 Summary of objectives..................... I

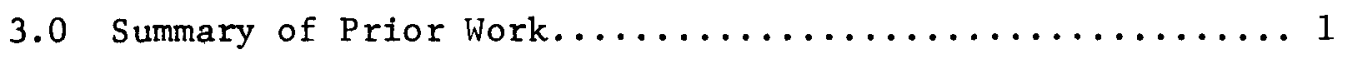

4.0 Summary of Current Progress.................. 2

2 SSBA-110 Project Administration.................. 5

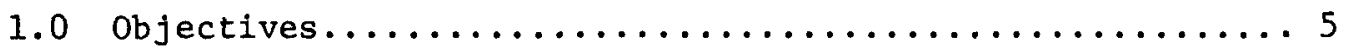

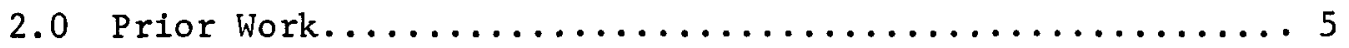

3.0 Current Progress........................ 5

3 SSBA-210 Evaluation of Austenitic Stainless Steel Cladding... 7

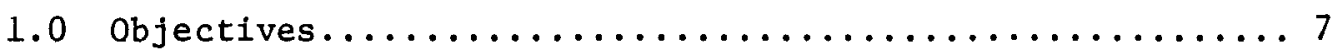

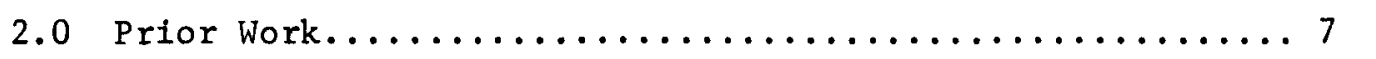

3.0 Current Progress........................ 8

3.1 Procurement and Material Handling........... 8

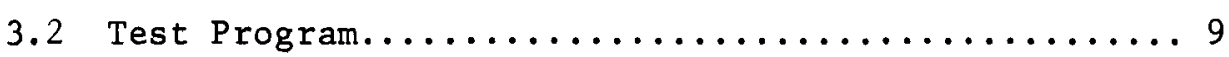

3.2.1 Non-Destructive Testing.............. 9

3.2.2 Biaxial Stress Rupture Tests............12

3.2.3 Uniaxial Creep...................... 15

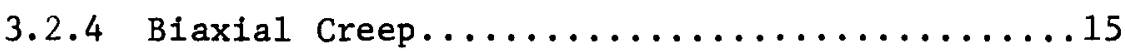

3.2.5 Biaxial Stress Rupture Morphology Correlation....................... 15

3.2.6 Biaxial Stress Rupture Strain Measurements... 18

3.2.7 Strain Variation Around Circumference of Tube Transverse Cross Section............19

3.2.8 Circumferent1al Strain Results..........25

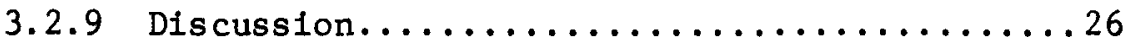

3.2.10 Metallographic Evaluation.............29

3.2.11 Discussion of Metallographic Results........ 34 
LIST OF FIGURES

Figure

Page

1 Eddy Current Traces Showing Defects in Type 316 Stainless

Steel Tubing.....................................

2 Photomicrographs Showing 0.00025-inch Defects in Surface of Type 316 Stainless Steel Tubing Detected with Eddy Current Inspection. ..............................

3 Biaxial Stress Rupture Results for Type 316 Stainless Steel Tubing in the Annealed and 20 Percent Cold Worked Conditions.. 14

4 Biaxial Stress Rupture Results for ARD, Item 9, Type 316 Stainless Steel Tubing in the 20 Percent Cold Worked, Double Vacuum Melted, Plug Drawn, Fine Grain Condition.............14

$5 \quad$ Plug Drawn Tubing - Longitudinal Strain Profiles for Post-Test Stress Rupture Specimens. $\lambda=$ Transverse Section, Circumferential Strain Variations; $\downarrow=$ Pin Hole Type Rupture; $X=$ Split

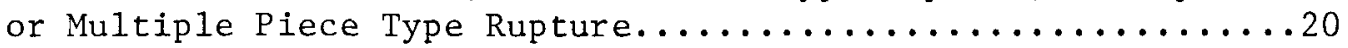

6 Planetary Swaged Tubing - Longitudinal Strain Profiles for Post-Test Stress Rupture Specimens. $\lambda=$ Transverse Section, Cicumferential Strain Variations; $\downarrow=$ Pin Hole Type Rupture; $\mathrm{X}=$ Split or Multiple Piece Type Rupture.................21

7 Plug Drawn, Annealed Specimens - Circumferential Strain Measurements Versus Angle Relative to Rupture Area..........22

8 Plug Drawn, Cold Worked Specimens - Circumferential Strain Measurements Versus Angle Relative to Rupture Area.........23

9 Planetary Swaged Specimens - Circumferential Strain Measurements Versus Angle Relative to Rupture Area.......... 24

10 Ratio of Actual Hoop Stress to Engineering Hoop Stress Versus $D / D_{0}$ for Internally Pressurized 0.230 in. by 0.200 in. Tubing at Constant Pressure.................. 27

11 Transverse Cross Sections of Post-Test Stress Rupture Specimens from Lot \# 42402 in the Plug Drawn, 20 Percent

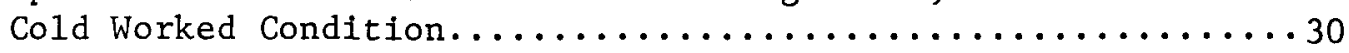

12 Transverse Cross Sections of Post-Test Stress Rupture Specimens from Lot \# 49193 in the P1anetary Swaged, 20

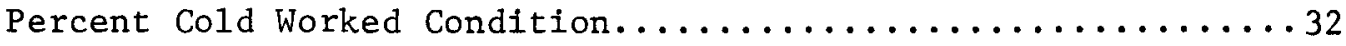




\section{LIST OF FIGURES (CONTINUED)}

Figure

13 Transverse Cross Sections of Post-Test Stress Rupture Specimen from Lot \# 49193 in the 20 Percent Cold Worked Condition - Areas 90 Degrees from Rupture................. 33

\section{LIST OF TABLES}

Table

1 Biaxial Stress Rupture Data for Type 316 Stainless Steel Tubing with 0.015 -Inch Wall Thickness..................13

2 Type 316 Stainless Steel Biaxial Stress Rupture Fracture Classification $\left(1300^{\circ} \mathrm{F}\right.$ Nominal Temperature $\ldots \ldots \ldots \ldots \ldots \ldots$

3 Type 316 Stainless Steel Biaxial Stress Rupture Fracture Classification $\left(1200^{\circ} \mathrm{F}\right.$ Nominal Temperature $) \ldots \ldots \ldots \ldots \ldots$ 


\section{SECTION 1}

INTRODUCTION

\subsection{GENERAL}

This is the ninth quarterly progress report and covers the work performed during the first quarter of FY-1971.

\subsection{SUIMARY OF OBJECTIVES}

This project is focused on the short term, and is concerned with steps to improve commercially available Type 316 austenitic stainless steels for use as cladding in LMFBR fuel pins. The overall project objective is to determine the influence of structure on mechanical properties of Type 316 austenitic stainless steel so that optimum specifications, which will assure maximum performance under LMFBR service conditions, can be selected.

The importance of structure on mechanical properties has been well demonstrated in the published literature. For example, in one series of experiments, [1] prestraining of Type 316 austenitic stainless steel, followed by a specific heat treatment to produce carbide precipitation, decreased the minimum creep rate at temperatures of interest to LMFBR by as much as a factor of 250, and increased creep rupture life by as much as a factor of 25.

Initially in the cladding development program, a survey will be made to determine tubing material property and microstructural variability based on procurement of tubing under an existing FFTF specification. This specification will be used as a starting point. Materials with various fabrication histories will be procured and evaluated in both the as-fabricated condition and after post-fabrication heat treatment. The relations between mechanical properties and structure will be investigated.

It is anticipated that this first phase of the cladding program will culminate at the end of FY-1972 with a definition of the most desirable mechanical and microstructural properties in austenitic stainless steel, to maximize the strength and ductility of the material under the most limiting LMFBR service conditions.

\subsection{SUMMARY OF PRIOR WORK}

All work related to the present investigations and performed prior to the present period has been fully reported in:

WARD-3791-26 "Stainless Steel Cladding Development Quarterly Progress Report for the Period Ending September 30, 1968." 

WARD-3791-29 "Stainless Steel Cladding Development Quarterly Progress Report for the Period Ending December 31, 1968."
WARD-3791-35 "Stainless Steel Cladding Development Quarterly Progress Report for the Period Ending March 31, 1969."
WARD-3791-41 "Stainless Steel Cladding Development Quarterly Progress Report for the Period Ending June 30, 1969."
WARD-4135-2 "Stainless Steel Cladding Development Quarterly Progress Report for the Period Ending September 30, 1969."
WARD-4135-5 "Stainless Steel Cladding Development Quarterly Progress Report for the Period Ending December 31, 1969."
WARD-4135-9 "Stainless Steel Cladding Development Quarterly Progress Report for the Period Ending March 31, 1970."
WARD-4135-12 "Stainless Steel Cladding Development Quarterly Progress Report for the Period Ending June 30, 1970."

\subsection{SUMMARY OF CURRENT PROGRESS}

Under Task SSBA-110, project administration and day-to-day 1iaison with the AEC continued.

Under Task SSBA-210, microcharacterization and mechanical property testing, including biaxial tensile, biaxial stress rupture, and both uniaxial and biaxial creep were continued on ARD vacuum melted materials.

Stress rupture tests were continued; the results from seven lots of material representing various combinations of the independent variables were compared.

Classification of the mode of rupture of post-test biaxial stress rupture specimens continued. Strain measurements of fifteen specimens were completed and results compared. Metallographic examination of selected specimens from this group was planned.

Non-destructive testing equipment was received and installed. Preliminary eddy currect tests were made for two lots of tubing.

Sixteen stress rupture tests were completed during the report period. Results from ARD, double vacuum melted, Type 316 tubing, in the cold worked condition and in the annealed condition were compared.

Upgrading of a uniaxial creep facility has been initiated so that low stress creep data may be obtained.

A total of 131 post-test stress rupture specimens were classified according to rupture type, stress level, and material, at both 1200 and $1300^{\circ} \mathrm{F}$. 
Nine of the fifteen post-test stress rupture speciments, which had been previously measured for longitudinal strain profiles, were further evaluated by circumferential wall thickness measurements at various locations along the length of the specimen. Examination of the variations in localized strain around the section circumference lead to some observations and evaluations relative to both material properties and mechanical effects on stress rupture results.

Five of these nine specimens were also examined metallographically. The change in slope in the stress rupture curve for the cold worked, planetary swaged material was correlated with recrystallization on the $O D$ of the tubing.

Tubing materials required for the current program were ordered from Superior Tube Co. 
9. 
SECTION 2

SSBA-110 PROJECT ADMINISTRATION

F. A. 3rassart, W. B. Heubel, and P. Murray

\title{
1.0 OBJECTIVES
}

The objectives of this task are to assure that the project is successfully completed, on schedule, within budget, and to the satisfaction of the Atomic Energy Commission (AEC); to assure compliance with contracted obligations; and to coordinate this project with other AEC-sponsored and Westinghouse-sponsored LMFBR development projects.

Overall project direction and day-to-day administration will be provided under this task. Plans and controls will be established and maintained, periodic reviews will be held with the AEC, correspondences and reports will be coordinated, and day-to-day technical and administrative liaison with the AEC will be provided.

\subsection{PRIOR WORK}

Schedule 189a/Work Plan for FY-1971 was prepared and submitted to the New York Operations Office. Technical work has continued on the basis of the work plan. The project is divided into the following tasks for FY-1971 administrative control.

\author{
SSBA-110 Project Administration \\ SSBA-210 Evaluation of Austentic Stainless Steel Cladding
}

\subsection{CURRENT PROGRESS}

The quarterly progress report, WARD-4135-12, for the period ending June 30 , 1970, was prepared and distributed.

WARD-4135-7, "Effect of Cladding Properties and Interactions," the final report for task SSBA-211 (FY-1970) was prepared and distributed. 
9. 


\section{SECTION 3 \\ SSBA-210 EVALUATION OF AUSTENITIC STAINLESS STEEL CLADDING}

M. G. Cowg 111, T. R. Padden, I. E. Ray,

II. J. Snyder, E. J. Tarby, and K. C. Thomas

\subsection{OBJECTIVES}

The objective of this task is to characterize in detail, by microstructural analysis, chemical analysis, and mechanical property testing, thin-wall stainless steel tubing fabricated under carefully controlled commercial practice. This information will be used to:

1. Enhance the understanding of the effect of fabrication processes and resulting structure on the properties of thin-wall tubing.

2. Provide out-of-reactor data required to predict and improve swelling behavior and strain limits of cladding in LMFBR environments.

The objective of a supplementary weldability investigation is to determine the effect of the degree of cold working on the weldability of Type 316 stainless steel tubing.

\subsection{PRIOR WORK}

A detailed test program was prepared. Air melted, annealed Type 316 stainless steel tubing, 0.300 -inch OD at three wall thicknesses $(0.010$, 0.012 , and $0.014-$ inch), and 0.250 -inch $O D \times 0.016$-inch was procured. Extensive biaxial mechanfcal property testing at $850,1000,1200$, and $1300^{\circ} \mathrm{F}$, and chemical and microstructural evaluation of the tubing were performed.

Cold worked (15 to 20 percent), air melted tubing and micropeened air melted tubing were also procured. A study to determine the effects of micropeening on mechanical properties was performed, and an investigation of the effects of cold work was inftiated.

All twelve lots of ARD vacuum melted tubing representing three melting practices, two grain sizes, and two conditions (20 percent cold worked and solution annealed) were received and accepted. Microcharacterization and mechanical property testing, including blaxial tensile, biaxial stress rupture, and both uniaxial and biaxial creep were initiated.

Chemical analysis and general metallographic characterization of the ARD vacuum melted tubing were completed. 
Comprehensive structural characterization of two ARD double vacuum melted, plug drawn tubing lots, including electron microscopy and probe analysis, as well as electron and $x$-ray diffraction analysis was completed.

Conprehensive structure characterization of the planetary swaged materials, including transmission and scanning electron microscopy, electron and $\mathrm{x}$-ray diffraction, and texture analysis by pole figures, was 75 percent completed.

Post-test stress rupture specimens have been classified according to rupture type, and microstructural evaluation of selected specimens has been initiated.

Biaxial stress rupture data scatter was evaluated, and a temperature correction procedure was proposed for the minor temperature variation $\left( \pm 15^{\circ} \mathrm{F}\right)$ inherent in the test.

A thermal aging study of several lots of Type 316 stainless steel was completed for times up to 5000 hours.

The experimental phase of an investigation on the effects of degree of cold work on weldability was completed; a summary is being prepared. 1 low cycle high strain fatigue study was initiated.

Comprehensive characterization, including texture evaluation, was completed for two lots of planetary swaged tubing and the results were compared to plug drawn material.

Biaxial tensile testing at room temperature and five elevated temperatures was completed for the vacuun melted steels program. Results were compared for the evaluation of the effects of the independent variables on the properties of tubing.

\subsection{CURRENT PROGRESS}

\subsection{PROCUREMENT AND MATERIAL HANDLING}

Quotations for the additional tubing materials required for the current test and development program have been received and evaluated. An order has been placed with Superior Tube Co. Westinghouse bar stock, (Heat \# 91695), required for this order, has been shipped. A partial delivery of finished tubing is expected by December 31, 1970, and the remainder of the order by January 15, 1971.

An order was placed in June, but not reported previously, for an additional 250 feet of 20 percent cold worked, PNL Type 316 stainless steel tubing for the WSA-4, 37 pin irradiation test. This lot is to have dimensions of $0.2315( \pm 0.001)$ inch oD by $0.2015( \pm 0.001)$ inch ID. The tubing is scheduled to be shipped in November.

Ultrasonic test standards for two lots of tubing, ARD Lot \# 42402 and PNL Ht \# 87210, have been received from Kenmar Corporation. An additional 
set of ultrasonic test standards for one of these (ARD Lot \# 42402) has been ordered from Metcut Corporation for comparison of standards from two sources.

The non-destructive test (NDT) and wall thickness charts for the PNL tubing, procured for the two 37 pin assemblies (WSA-3 and WSA-4), were received from WADCO.

\subsection{TEST PROGRAM}

\subsubsection{Non-Destructive Testing}

The non-destructive testing equipment was received and installed. Test runs were initiated on the instruments and auxiliary equipment to be used for the non-destructive characterization of cladding materials.

Air gauging has been installed and is now operational.

Debugging and calibration procedures are being conducted on the available ultrasonic testing equipment which will be used for several functions (average wall-thickness measurements, eccentricity, and defect evaluation):

The ultrasonic wall thickness equipment has been made operational. Calibration is in progress.

The eccentricity measuring unit has not yet been received from the manufacturer; delivery is expected during the next reporting period.

During the preparation procedures, one amplifier module in the ultrasonic defect measuring equipment was found to be inoperable. The unit was returned to the manufacturer, repalred, and is now enroute to ARD.

Test runs were made using the eddy current equipment to test for defects. The unit is successfully detecting OD and ID defects in standard notched tubing to sizes of $1 / 2-\mathrm{mil}$ deep by $30-\mathrm{mils}$ long by $2-\mathrm{mils}$ wide.

The ultrasonic standards were prepared by Kenmar Corporation utilizing ARD Lot \# 42402 and PNL HT \# 87210 tubing. An additional set of ultrasonic test standards for ARD Lot \# 42402 has been ordered from Metcut Corporation for comparison of standards from two sources.

A tube length from ARD Lot \# 42402 and from PNL HT \# 87210 were subjected to eddy current evaluation. Figure 1 shows a section of the strip chart recordings from each of the tubes, indicating outside diameter flaws. The respective flaws found in each of the tubes are shown in Figure 2. These defects were relatively shallow $(0.00025$ inch) and may have resulted from handling.

A 1iterature review is being conducted to explore the methods used for determining the degree of cold work and grain size of small diameter, thin- 


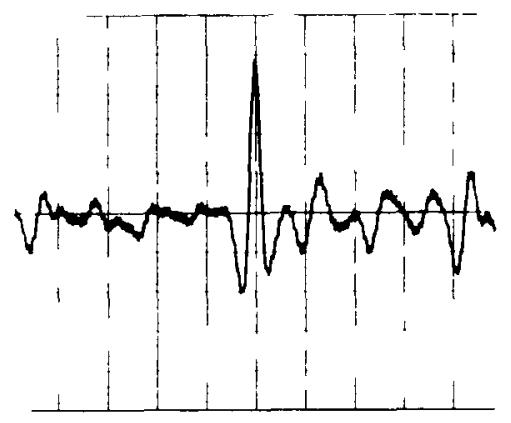

STANDARD 0.0005 in. DEFECT
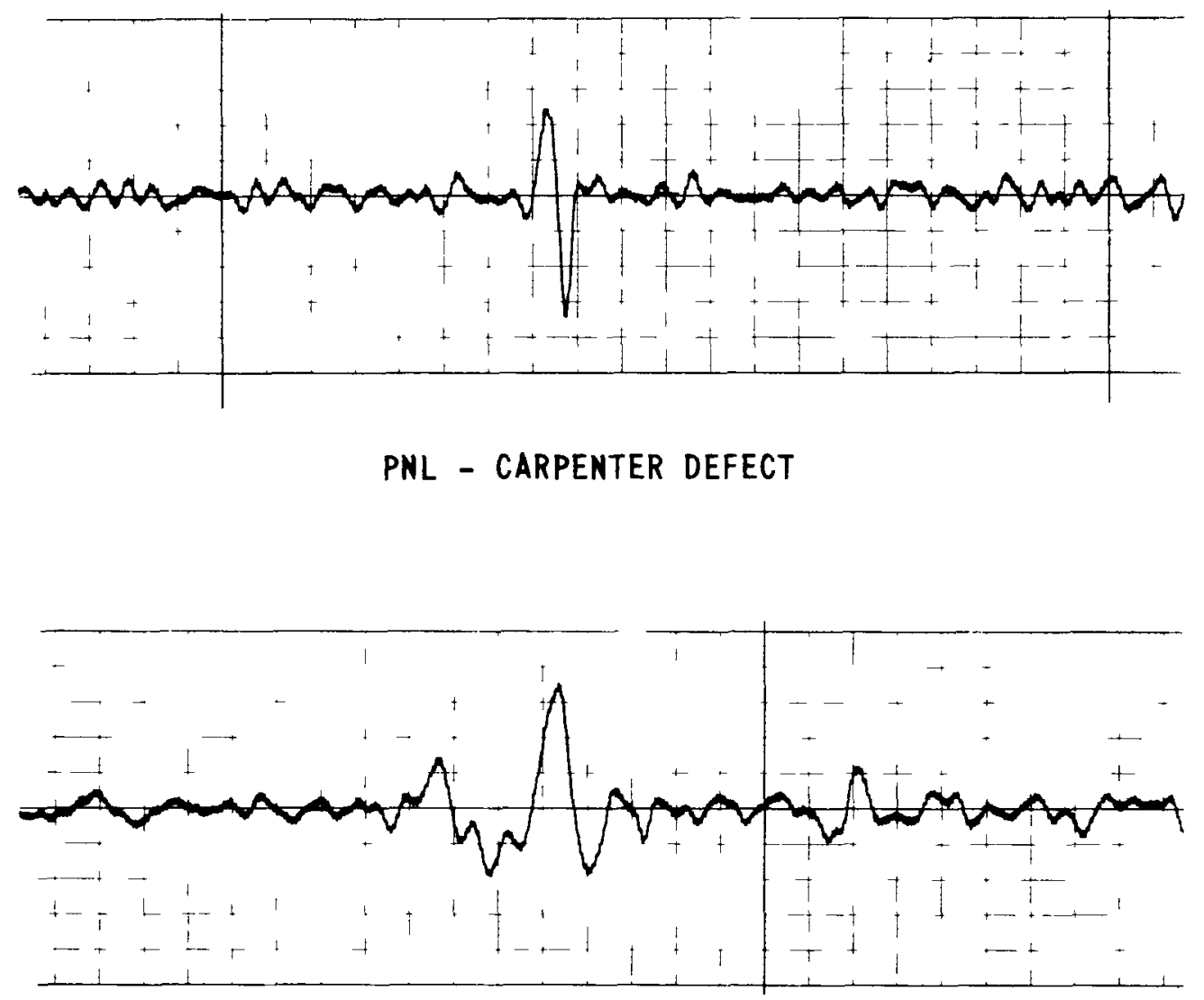

ARD -SUPERIOR DEFECT

Figure 1. Eddy Current Traces Showing Defects in Type 316 Stainless Stee1 Tubing 


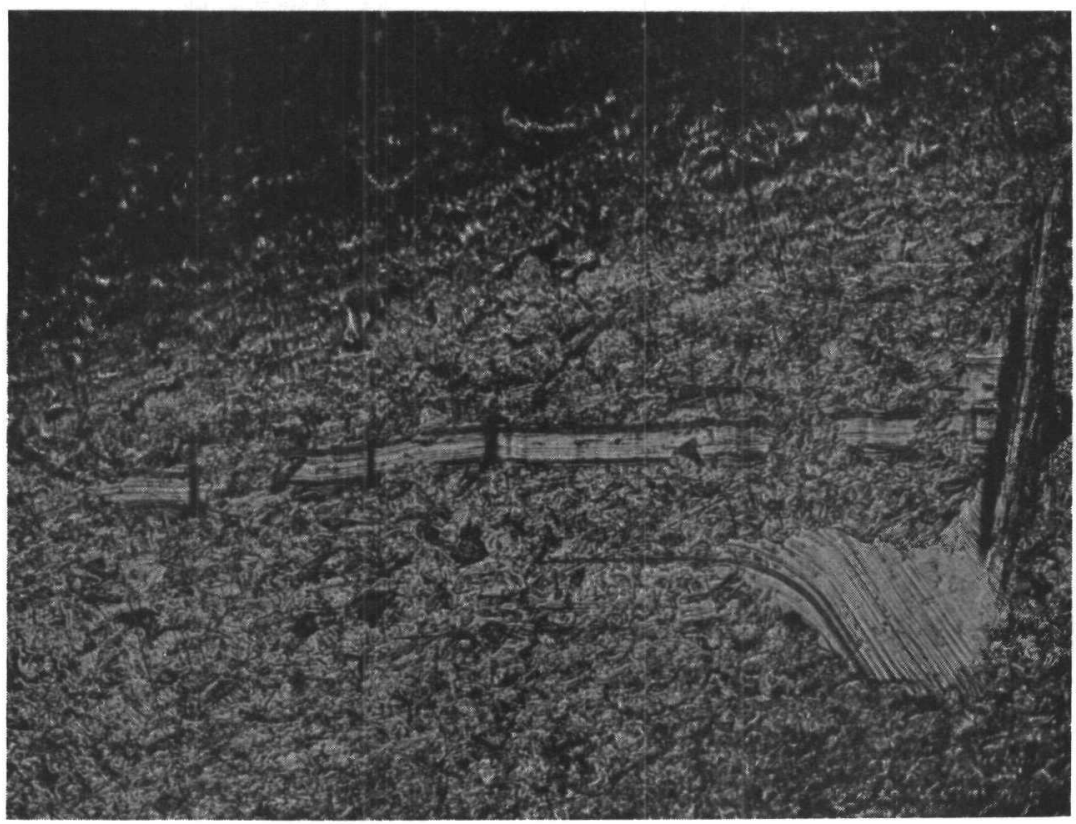

PNL - CARPENTER

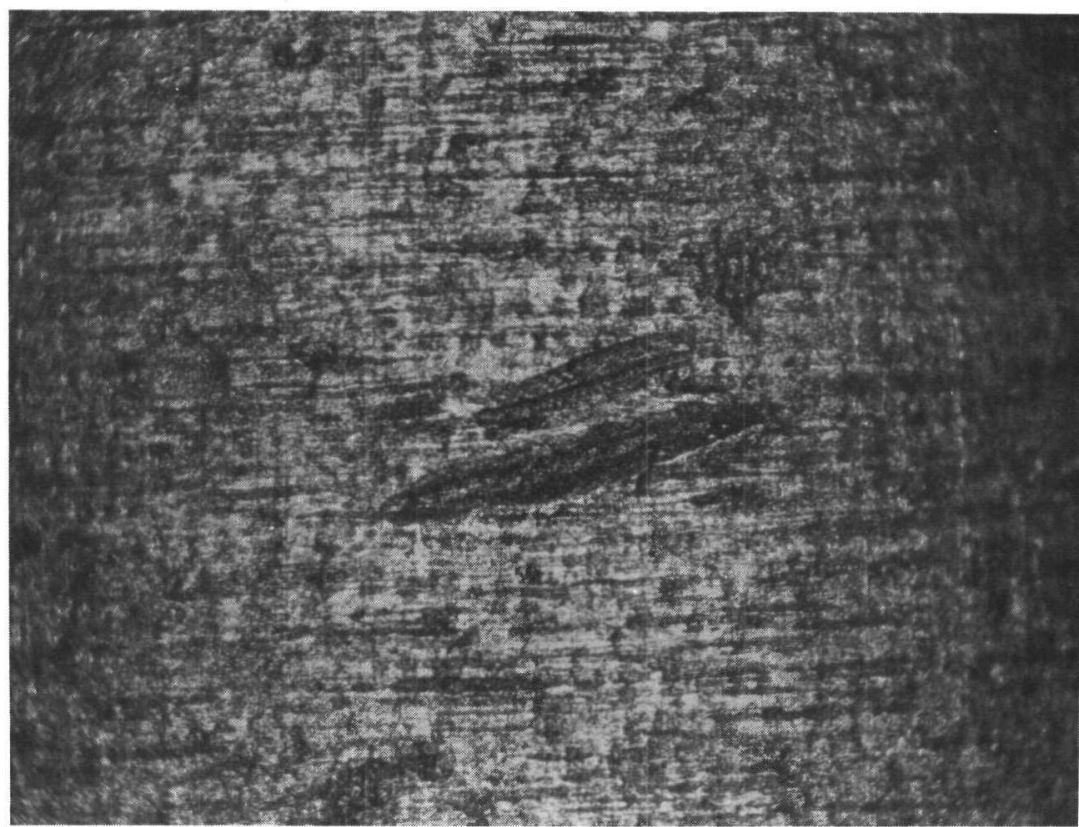

ARD - SUPERIOR

Figure 2. Photomicrographs Showing 0.00025-inch Defects in Surface of Type 316 Stainless Steel Tubing Detected with Eddy Current Inspection 3931- 10 
walled Type 316 stainless steel tubing. The three approaches presently being evaluated for this application are:

1. Ultrasonics using the Rayleigh "Critical Angle" versus amplitude to show different degrees of cold work and grain size. [2-7]

2. Magnetic permeability (ratio of electromagnetic induction to magnetic force) as determined by a low-frequency, eddy-current bridge. $[8,9]$ The permeability is plotted as a function of degree of cold work.

3. Magnetic retentivity as determined by a magnatron following magnetization of the sample by an electromagnet. [10]

Presently, the ultrasonic method appears most attractive to ARD for the following reasons:

1. The ultrasonic method affords the better opportunity for determining simultaneously both degree of cold work and grain size.

2. The ultrasonic technique has been developed to a greater extent than the magnetic method.

Equipment plans for the ultrasonic method of determining degree of cold work and grain size have been secured and are now being reviewed.

\subsubsection{Biaxial Stress Rupture Tests}

The results of sixteen biaxial stress rupture tests are presented in Table 1. Most of the tests completed during this period were long-term tests, in the range of 1000 to 2000 hours. Tests have continued at $1300^{\circ} \mathrm{F}$ to compare the different processing variables: vacuum melting practice, plug drawing, planetary swaging, annealing, 20 percent cold working, and fine and coarse grain structures. The latest results support the conclusions of previous reports.[11,12] Initial indications show that several lots of 20 percent cold worked tubing have a slope change in the stress rupture curve at about 900 to 1000 hours. A comparison of annealed and 20 percent cold worked tubing of the same melting practice and grain size shows the cold worked stress rupture curve to change slope at 900 hours, whereas the curve for the annealed material shows no slope change (Figure 3 ). Thus the two curves intersect, indicating that the annealed material has better rupture life, at lower stress levels, than the cold worked material. Additional tests are being performed at $1200^{\circ} \mathrm{F}$ on similar tubing lots. Figure 4 shows a comparison of 1200 and $1300^{\circ} \mathrm{F}$ data for double vacuum melted, 20 percent cold worked, fine grain tubing.

Several tests were run as spot checks on tubing that had been micropeened after manufacture; previous results were inconcluslve. There appears to be no difference in stress rupture life due to micropeening for annealed or 
20 percent cold worked, double vacuum melted, fine grain tubing. No more work on micropeened material 18 planned.

A maforfty of the stress rupture tests now running are expected to rupture in the range of 2000 to 5000 hours. A third furnace, holding nine specimens, has been made operational to accommodate the long-term specimens and additional short term specimens.

Design work has been initlated on a furnace or series of furnaces to perform biaxial stress rupture testing in inert atmosphere. Present design calls for capability to test five to ten tubes in an inert atmosphere and internally pressurized with an inert gas. Pressure capacity will range from 8000 to

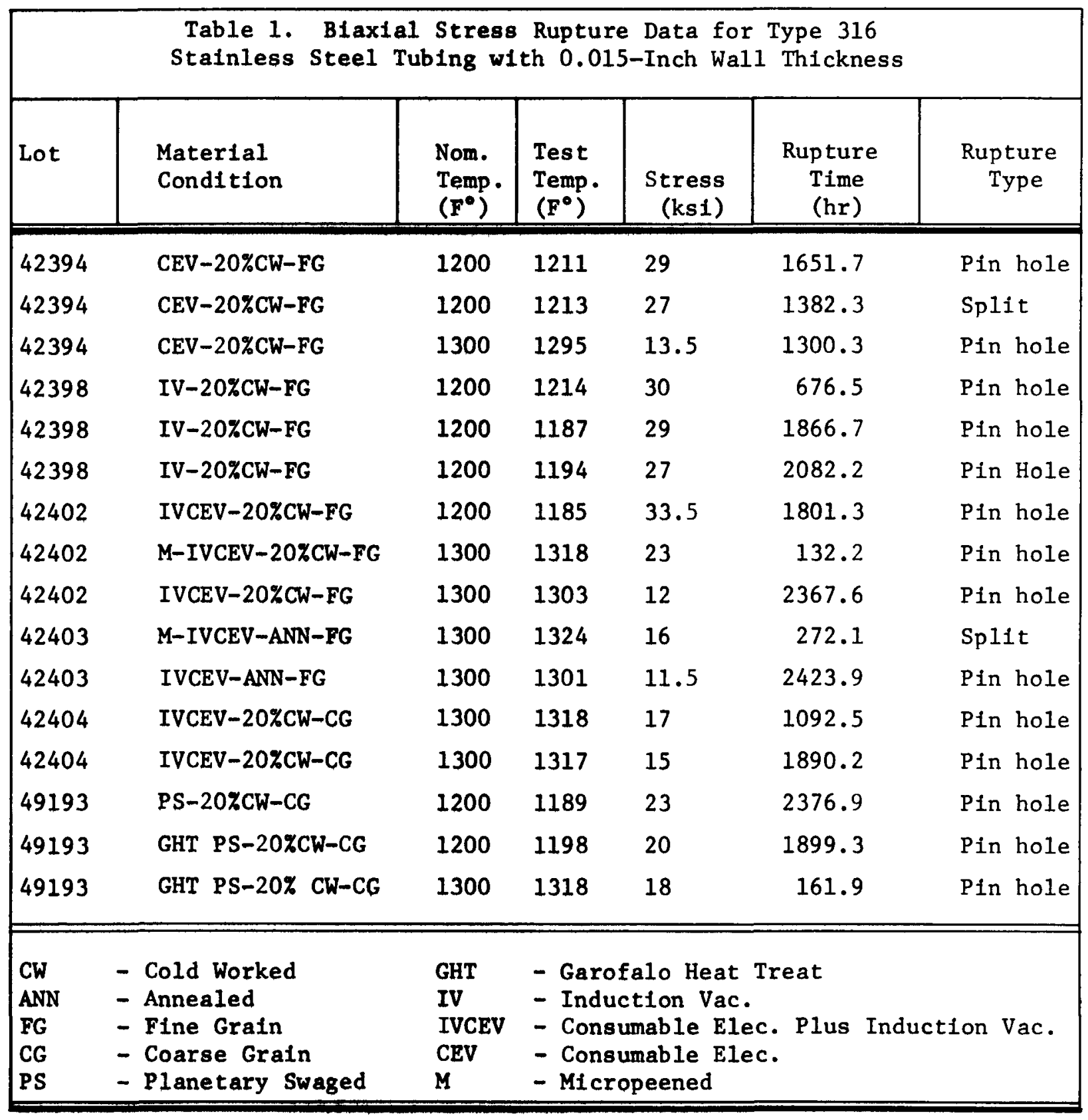




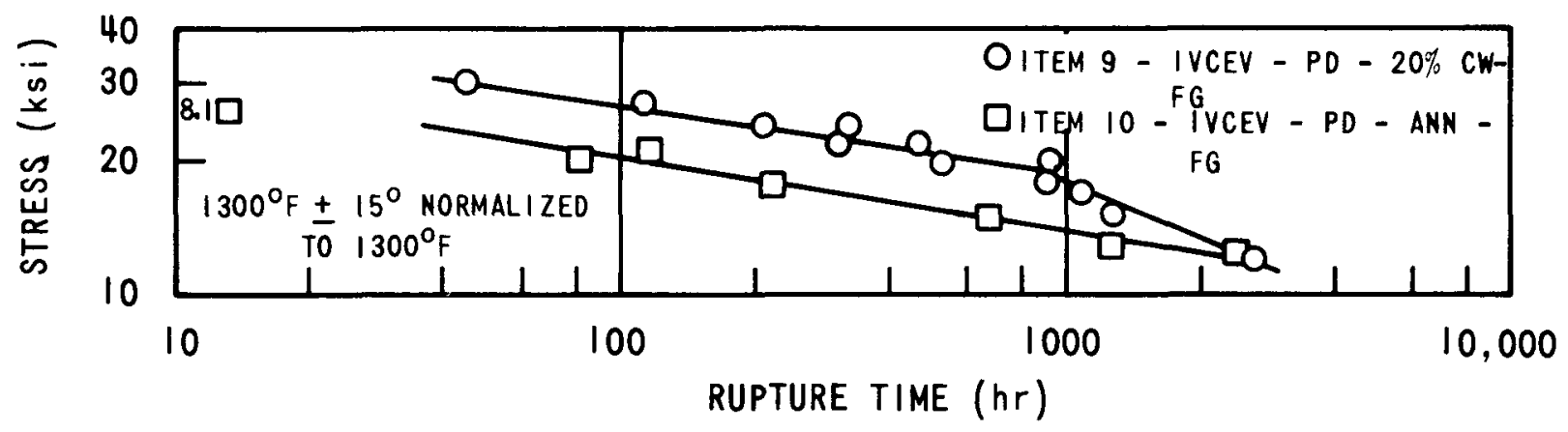

Figure 3. Biaxial Stress Rupture Results for Type 316 Stainless Steel Tubing in the Annealed and 20 Percent Cold Worked Conditions

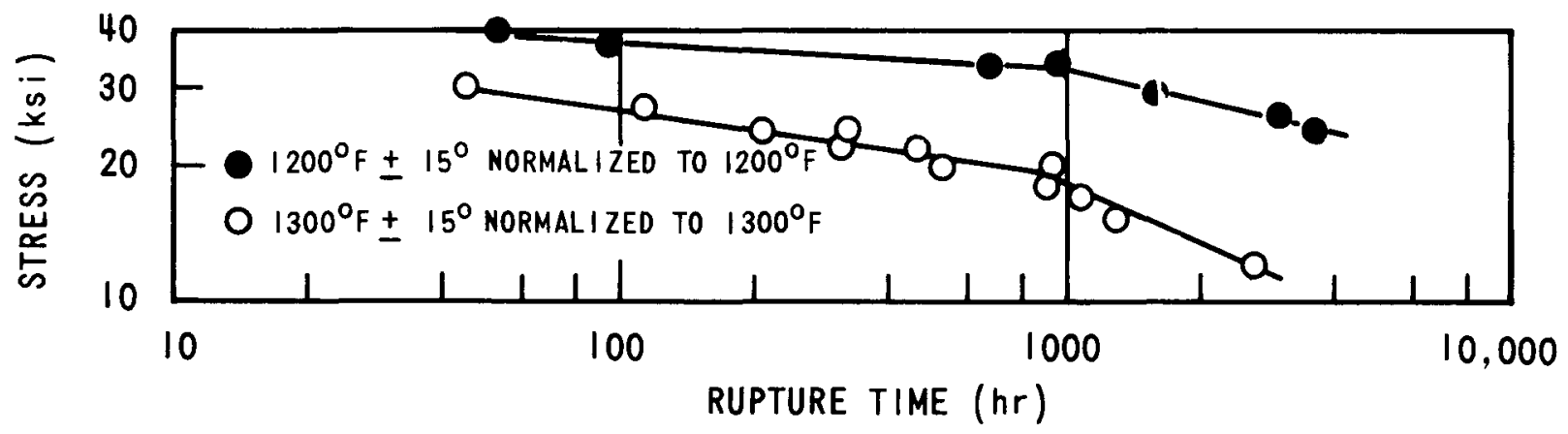

Figure 4. Biaxial Stress Rupture Results for ARD, Item 9, Type 316 Stainless Stee1 Tubing in the 20 Percent Cold Worked, Double Vacuum Melted, Plug Drawn, Fine Grain Condition

$3931-2$ 
50,000 psi hoop stress. The des1gn objective is to achieve a temperature variation no more than $\pm 1^{\circ} \mathrm{F}$ over the nine inch test section. This furnace will have the capability of allowing removal of individual samples for strain measurements during the test.

\subsubsection{Uniaxial Creep}

Platinum strip extensometers have been attached to five creep specimens for testing of ARD Lot \# 42402 (double vacuum melted, fine grain, 20 percent cold worked) Type 316 stainless steel tubing. The creep testing units are presently being equipped with an optical window and Gaertner microscope for strain measurements. Creep units will be checked for stability and temperature fluctuation before testing. Problems may be expected in sensitivity of measurement and in furnace temperature variations. The precision of measurement of the microscope is $20 \times 10^{-6}$ inches, which is in the range of creep strain to be encountered at low stress testing.

\subsubsection{Biaxial Creep}

The biaxial creep unit is being checked, using the Gaertner microscope to give an independent calibration of the strain measurement determined by the LVDT method previously used.

\subsubsection{Biaxial Stress Rupture Morphology Correlation}

Tables 2 and 3 give the rupture classifications for 131 stress rupture specimens which have been classifled according to rupture type, stress level, and material, at both 1200 and $1300^{\circ} \mathrm{F}$. These addftional results further support the observations reported previously. [12]

1. The cold worked, planetary swaged material tends to rupture with a Type 1 fracture (Pin hole).

2. The annealed materials tend to fall with a high fraction of Type 2 or Type 3 rupture (Splits or multiple pieces).

3. The cold worked, plug drawn materials are intermediate between failure Types 1 and 2 .

4. In general the tendency for Type 1 rupture is greater at lower stresses.

A varfety of measurements relative to rupture have already been made and others are planned with the ultimate objective of understanding the causes for these differences in rupture morphology. 
Table 2. Type 316 Stainless Steel Biaxial Stress Rupture Fracture Classification (1300 F Nom. Temp.)

\begin{tabular}{|c|c|c|c|c|c|c|c|c|c|c|c|c|c|c|c|c|c|c|c|c|c|c|c|c|}
\hline \multirow[b]{2}{*}{$\mathrm{Melt}$} & \multirow[b]{2}{*}{ Condition } & \multirow{2}{*}{$\begin{array}{c}\text { ASTM } \\
\text { Grain Size }\end{array}$} & \multicolumn{22}{|c|}{ Stress $\times 1000$ psi } \\
\hline & & & 11 & 12 & 13 & 14 & 15 & 16 & 17 & 18 & 19 & 20 & 21 & 22 & 23 & 24 & 25 & 26 & 27 & 28 & 29 & 30 & 31 & 32 \\
\hline & $\mathrm{PD}-\mathrm{CW}$ & $9 / 9.5$ & & & & 1 & & 1 & & 1 & & 2 & & 1 & & 1 & & 1 & & 2 & & 1 & & \\
\hline & PD-ANN & 8 & & & & 1 & & 1 & & 2 & & 2 & & 1 & & 2 & & & & & & & & \\
\hline & $\mathrm{PD}-\mathrm{CW}$ & $5.5 / 6$ & & & & & & & & & & & & 1 & & 1 & & 1 & & 1 & & 2 & & \\
\hline \multirow{2}{*}{ P } & $\mathrm{PD}-\mathrm{CW}$ & 9 & & & & & & & & 1 & 1 & 1 & & 2 & & 2 & & 2 & & 2 & & 1 & & \\
\hline & $\mathrm{PD}-\mathrm{CW}$ & $5.5 / 6$ & & & & & & & & & & 1 & & 1 & & 1 & & 2 & & 1 & & 1 & & \\
\hline \multirow{7}{*}{ 点 } & $\mathrm{PD}-\mathrm{CW}$ & 9 & & 1 & & & 1 & $2 *$ & 1 & 1 & & 1 & & 2 & $1 *$ & 3 & & I & 1 & 1 & & 2 & \multirow{7}{*}{2} & \multirow{7}{*}{1} \\
\hline & PD-ANN & 8 & & 1 & 1 & 3 & 2 & 1 & & 2 & & 2, & 2 & 2 & & & 3 & & & & & & & \\
\hline & $\mathrm{PD}-\mathrm{CW}$ & $5.5 / 6$ & & & & & 1 & & 1 & & 1 & 1 & 2 & 1, & & 1,2 & & 1 & 2 & 2 & 2 & 3 & & \\
\hline & PD-CW GHT & 9 & & & & & & & & & & 1 & & 1 & & 3 & & 3 & & 3 & & 3 & & \\
\hline & $\mathrm{PS}-\mathrm{CW}$ & 6 & 1 & & 1 & & & 1 & & & & 1 & & 1 & & 1 & & 1 & & 1 & & 1 & & \\
\hline & PS-AMM & 6 & & & & 1 & 1 & 2 & & 2 & 2 & & 2 & & 3 & & & 2 & & & 3 & & & \\
\hline & PS-CW GHT & 6 & & & & & & & & 1 & & & 1 & & & & & 1 & & & 2 & & & \\
\hline
\end{tabular}

*Micropeened

Failure Type
1. Pinhole
PD - Plug Drawn
CEV - Consumable Elec.
2. Split
PS - Planetary Swaged
IV - Induction Vacuum
3. Pieces
CW - 20\% Cold Worked
IVCEV - Consumable Elec. Plus Induction Vacuum
ANN - Annealed
GHT - Garofalo Heat Treat 


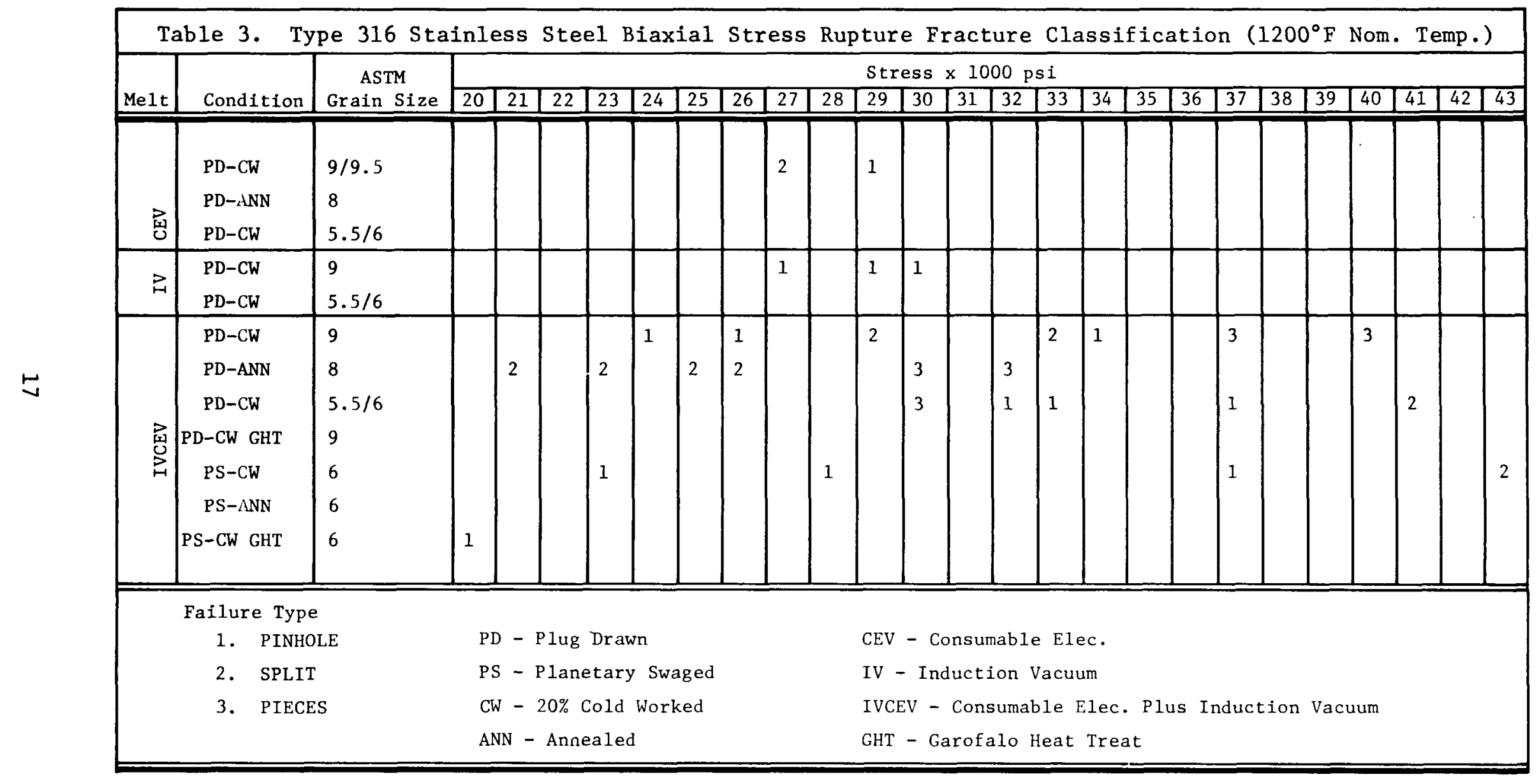




\subsubsection{Biaxial Stress Rupture Strain Measurements (Previous Results)}

Biaxial stress rupture is used in the Cladding Development Program to obtain design data for Type 316 stainless steel and to characterize tubing having various processing histories. In biaxial.stress rupture tests, the tubing is internally pressurized with gas to give a specific initial hoop stress, and held at a constant temperature until rupture occurs. The rupture time is recorded and the results are presented in the form of standard stress rupture plots of $10 \mathrm{~g}$ stress versus $\log$ rupture time. This approach has been used extensively to compare various lots of 0.230 in. OD $\times 0.200 \mathrm{in.}$. ID Type 316 stainless steel tubing made by different vacuum melting practices, different fabrication procedures, and finished to two different grain sizes in both the annealed condition, and the 20 percent cold worked condition.

The result obtained thus far indicate little difference in rupture life due to vacuum melting practice; some difference due to grain size; marked difference due to fabrication process for the cold worked condition; and extensive difference between the annealed condition and the 20 percent cold worked condition.

Post-test specimens from 131 stress rupture tests, representing the various combinations of the material variables, have been classified according to rupture morphology. In general, it has been found that plug drawn, annealed specimens rupture into multiple pieces or contain large splits forming a flap on the tubing wall, whereas cold worked planetary swaged specimens almost invariable rupture with a fine, narrow pin hole fracture less than $3 \mathrm{~mm}$ long. Annealed, planetary swaged tubing and cold worked, plug drawn tubing are intermediate between the two extremes. It was also observed that the tendency to form pin hole fractures, or less severe split type fractures increases with lower stresses (longer rupture times) for a given material.

During the previous report period, 15 of these post-test specimens, representing various combinations of the variables, were selected for further evaluation. Diametral strain profile measurements were made along the lengths of the specimens including the area of the rupture and the results plotted as average $\triangle D / D$ versus position along the length of the specimens. $[11]$ The $\triangle D / D$ for the non-ruptured areas of the tubes were calculated from the average of two perpendicular diameter measurements. For those areas containing pin hole ruptures, the equivalent circumference and thus the equivalent diameter was calculated from diameter measurements corrected for the width of the pin hole. For the areas containing splits, the circumference was measured directly using strips of lead as described previously.[11]

In general it was found: there was non-uniform average strain $(\Delta D / D)$ along the length of the specimens; the rupture area had the greatest strain in almost every specimen; the annealed materials had much greater $\triangle \mathrm{D} / \mathrm{D}$ 's than the cold worked materials; and in general, the specimens that had the highest average $\Delta \mathrm{D} / \mathrm{D}^{\prime}$ 's also had the highest diameter non-uniformity along the length (i.e., localized bulging). 
To increase the understanding of why these materials behave differently, nine of the fifteen specimens described previously were further analyzed during the current report period, but in this case, they were analyzed from the viewpoint of variation in localized strain around the circumference of the tube at specific cross sections of these specimens. Examination of the variations in localized strain around the section circumference led to some informative observations and evaluations relative to both the material properties and mechanfcal effects on stress rupture results, and indicated promising directions for future tests and observations in the planned investigation of fabrication defects.

\subsubsection{Strain Variation Around Circumference of Tube Transverse Cross Section}

In the previous report [11] strain profile measurements based on average diameters or equivalent diameters corrected for rupture width were plotted as a function of position along the length of the stress-rupture tubes. The longitudinal strain profile plots for the nine specimens, further evaluated during the current report period, are shown in Figures 5 and 6 . Included in these figures are the locations of the tube transverse cross sections used in the current analysis. At least two transverse sections were taken from each specimen. One section was taken through the fracture area, and at least one additional section at some location of interest along the strain profile curve.

The cross sections were cut, mounted, and metallographically polished. The wall thicknesses were measured using a light microscope equipped with a Filar eyepiece, calibrated against a standard stage micrometer. For the split-type rupture specimens where the section could not be mounted perpendicular to the plane of polish, the observed wall thicknesses were corrected for the tilt angle. Wall thickness measurements $\left(t_{i}\right)$ were made at five polar-angular positions around the circumference of the ruptured specimen sections and at four positions around the non-ruptured sections.

The rupture area was arbitrarily designated as the zero degree position and wall-thickness measurements made at approximately $+10,-10,+90,-90$ and 180 degrees. The non-ruptured specimens were measured at $0,+90,-90$, and 180 degrees. The angular orientation of the non-ruptured section, relative to the ruptured section in the same specimen, was maintained. From these thickness measurements, $\Delta t / t_{0}$ values (a measure of the local strain) were calculated, where $\Delta t$ is the change in wall thickness and $t_{0}$ is the average initial wall thickness calculated from the certified maximum and minimum $O D$ 's and ID's for the particular tubing lot. In presenting the results, $\Delta t / t$ o values were plotted as a function of circumferential angle for each transverse section. The greatest source of error in the results originated with the use of the certifled lot dimensions for the $t_{o}$. This source is estimated to induce a maximum error of about \pm 1.5 percent absolute in the $\Delta t / t_{0}$ data.

The results are given in Figures 7,8 , and 9 . The data points for each section were arbitrarily connected by straight lines except for the rupture areas which are left open. In plotting the results, the orientations of 

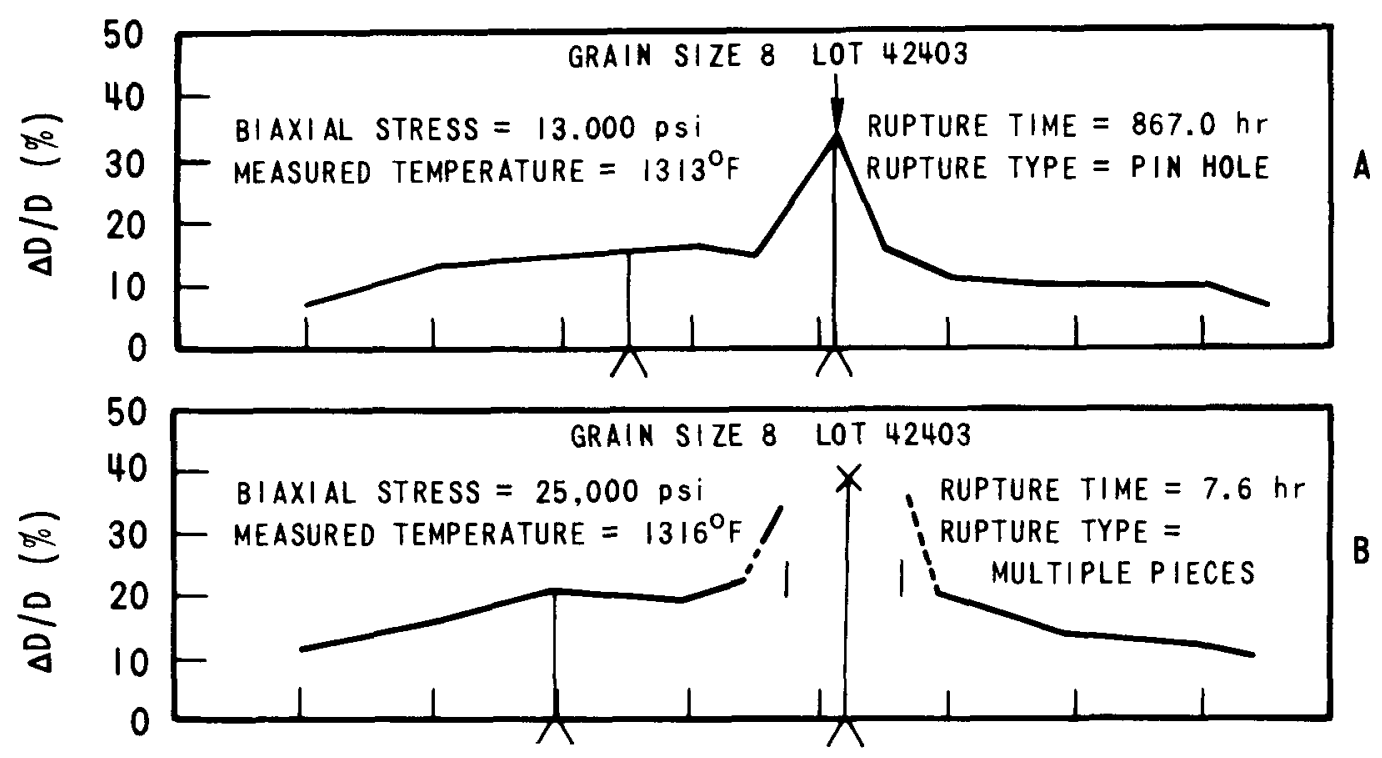

ANNEALED TUBING
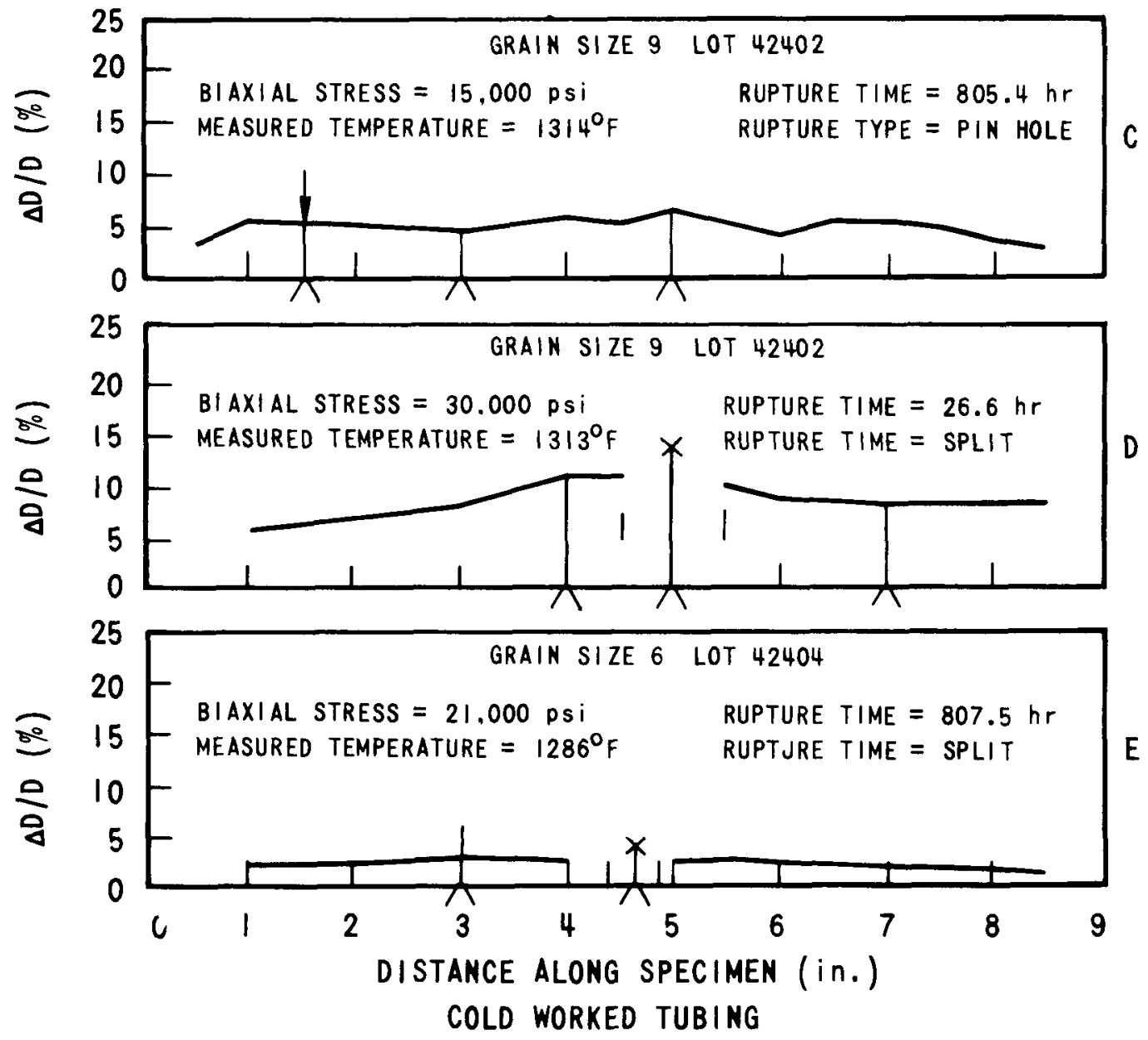

Figure 5. Plug Drawn Tubing - Longitudinal Strain Profiles for Post-Test Stress Rupture Specimens. $\lambda=$ Transverse Section, Circumferential Strain Variations; $\boldsymbol{l}=$ Pin Hole Type Rupture; $X=$ Split or Multiple Piece Type Rupture 

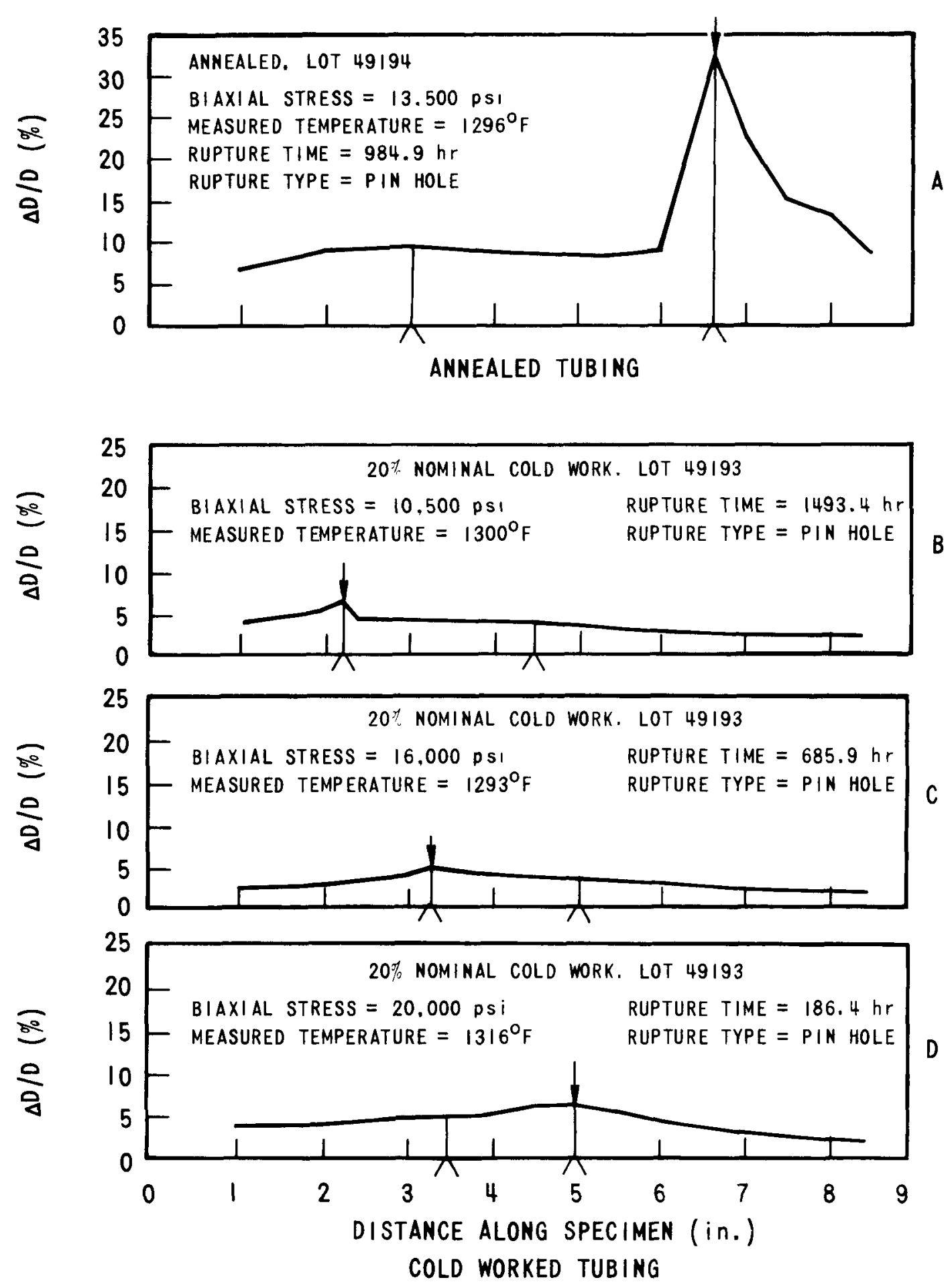

Figure 6. Planetary Swaged Tubing - Longitudinal Strain Profiles for PostTest Stress Rupture Specimens. $\lambda=$ Transverse Section, Circumferential Strain Variations; $\boldsymbol{\gamma}=$ Pin Hole Type Rupture; $X=$ Split or $3931-4$ Multiple Piece Type Rupture 

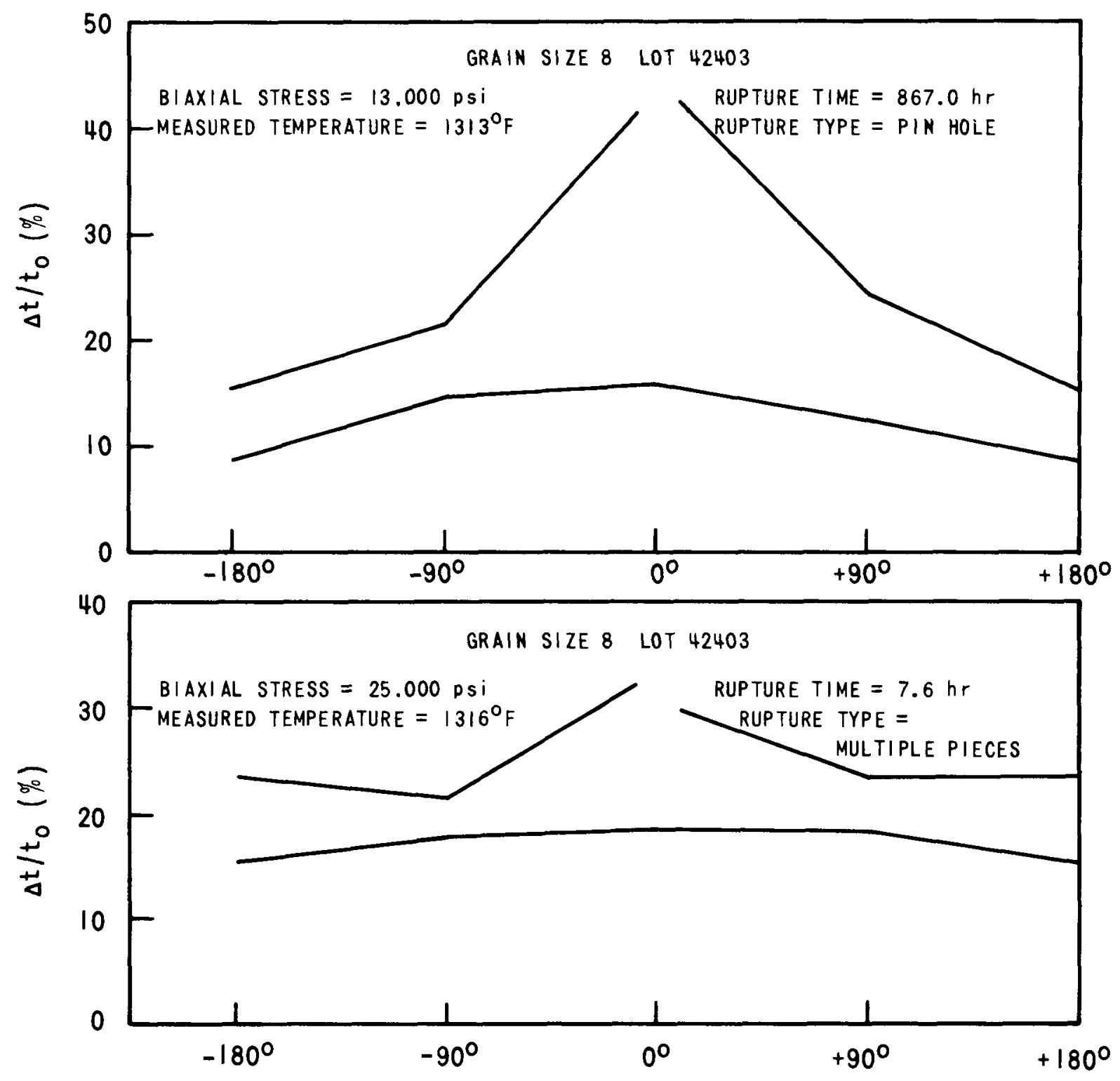

Figure 7. Plug Drawn, Annealed Specimens - Circumferential Strain Measurements Versus Angle Relative to Rupture Area 

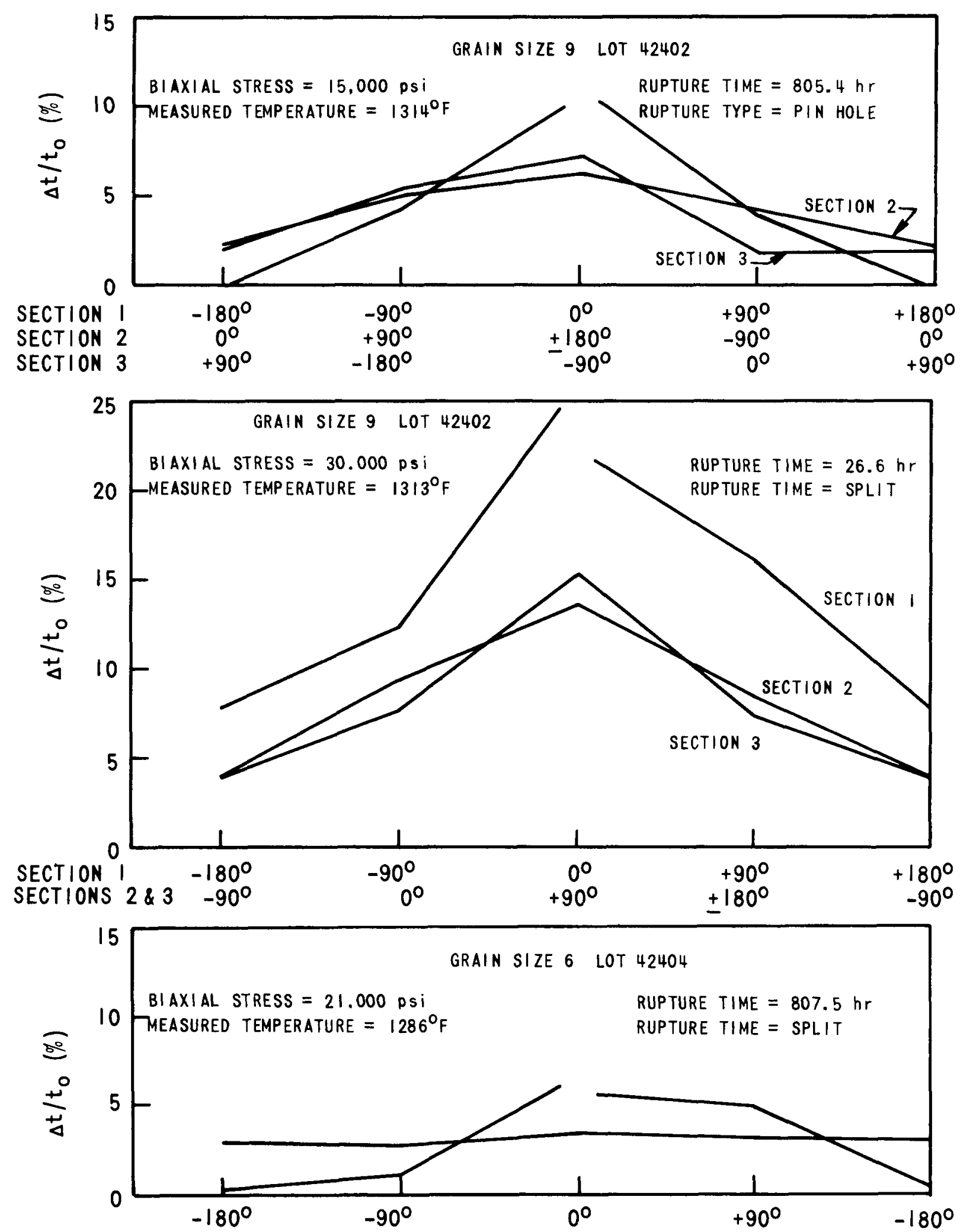

Figure 8. Plug Drawn, Cold Worked Specimens - Circumferential Strain Measurements Versus Angle Relative to Rupture Area

$3931-12$ 

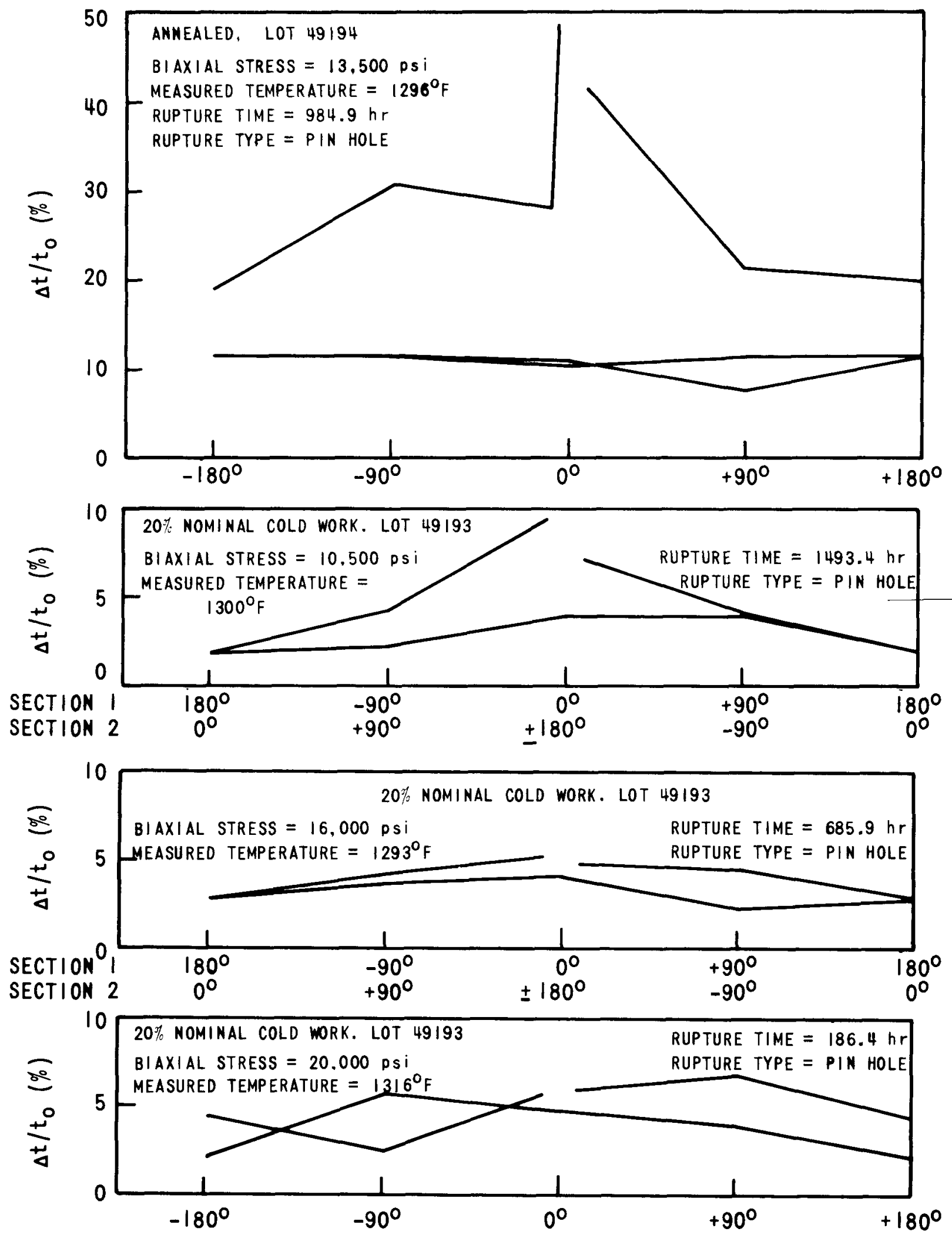

Figure 9. Planetary Swaged Specimens - Circumferential Strain Measurements Versus Angle Relative to Rupture Area 
some sections were rotated, as indicated in the figures, to bring positions of maximum strain into coincidence. It should also be noted that there is a difference in the $\Delta t / t_{o}$ scale factor between the annealed specimen and the cold worked specimen plots.

The percent wall thickness reduction, $\Delta t / t_{O}$, is used here as a measure of the percent deformation or the local strain. Its relationship to $\triangle D / D$ will be treated in Paragraph 3.2.9.

\subsubsection{Circumferential Strain Results}

There are a number of direct observations which can be made from Figures 7 , 8 and 9:

1. All of the specimen sections containing the rupture areas and most of the other sections showed non-uniform wall thickness reduction during test, indicating some type of circumferential heterogenity in pretest tubing.

2. In every specimen, the maximum $\Delta t / t_{0}$ observed was found in the section containing the rupture and, except for one section out of the nine measured, the maximum $\Delta t / t_{0}$ was located circumferentially near the rupture.

3. The annealed materials had the highest $\Delta t / t_{0}$ values as would be expected since they had the highest average ductilities as measured by $\Delta \mathrm{D} / \mathrm{D}$. Also, the annealed materials had in general the highest degree of non-uniformity in wall thickness reduction as measured by the ratio of maximum to minimum $\Delta t / t_{0}$ in the rupture specimens.

4. In both the plug drawn, cold worked and planetary swaged, cold worked specimens, the relative positions of the $\Delta t / t_{0}$ maxima in the nonruptured sections were not aligned with the maxima of the ruptured specimens, indicating that the source of the pre-test non uniformity was not longitudinally aligned. In the annealed, plug drawn specimens the maxima were aligned so no positive statement can be made. In the annealed, planetary swaged specimen there was no significant maximum in the non-ruptured section.

5. In comparing the three coarse-grained, planetary swaged, cold worked specimens, the ruptured section from the longest test (lowest stress) showed the highest maximum $\Delta t / t_{0}$ and the greatest non uniformity.

6. In contrast to the planetary swaged specimen, plug drawn, cold worked specimens from the shorter test had the higher $\Delta t / t_{0}$. However, the greater non uniformity was still found in the specimen from the longer test. In this pair of specimens one rupture was a pin hole and the other a split.

7. The coarse-grained, plug drawn, cold worked specimen showed generally lower $\Delta t / t_{0}$ values than the fine-grained, plug drawn, cold worked specimens, and less uniformity than the coarse-grained, planetary swaged specimens. Its rupture morphology was also a split. 


\subsubsection{Discussion}

The general observation of non-uniform straining is perhaps the most significant result in these nine Type 316 stainless steel specimens representing five fabrication, grain size, and cold work combinations.

Two sources which could cause the observed non-uniform circumferential straining during test are temperature differences and deviation from a homogeneous, uniform-walled circular cross-section in the starting material. Circumferential temperature variation at specific locations along the length of the specimens is not a reasonable cause for the observed nonuniform wall thickness reductions in these transverse sections. The maximum temperature variation over the whole nine inch length of the specimen was only $15^{\circ} \mathrm{F}$ and test conditions were such that very little circumferential temperature variation would be expected. The most probable cause is some type of circumferential heterogeneity in the pretest tubing, and wall thickness variation is the most likely suspect. This suspicion cannot be substantiated with experimental data since insufficient data are presently available; however, consideration of the expected effects of nonuniform wall thickness leads to results which are consistent with the observations and thereby indicate promising direction for future tests.

In biaxial stress rupture tests such as these, the tubing is internally pressurized with gas to give a specific initial hoop stress and held at a constant pressure and temperature until rupture occurs. The rupture time is recorded and the results are presented in the form of standard stress rupture plots of $\log$ engineering stress versus $\log$ rupture time. The engineering stress plotted for the test, is the initial hoop stress defined as follows for thin-walled tubing:

$\sigma=\frac{P D}{2 t}$

Where:

$P=$ pressure

$D=$ pretest diameter at the mid wall

$t=$ pretest wall thickness

In this type of test (conducted at constant pressure), as the specimen increases in diameter and the tube wall decreases in thickness, the actual hoop stress increases as a result of both the increase in diameter and the decrease in wall thickness. It can be seen in Figure 10 that the ratio of actual stress to the engineering stress (initial hoop stress) increases rapidly with $\Delta \mathrm{D} / \mathrm{D}_{\mathrm{O}}$. This plot was calculated for $0.230-i n$. OD by $0.200-i n$. ID tubing, using the same equation for the stress as given previously, but substituting the actual mid-wall diameters and wall thickness for the various $\Delta \mathrm{D} / \mathrm{D}_{\mathrm{O}}$ value and assuming uniform hoop strain and no negligible longitudinal straining. Assuming no strain hardening or any other process which would tend to offset the effect of increased diametral strain one would expect the strain rate to accelerate as the test proceeds as a result of the increased strain, and this could lead to an explosive type of rupture. 


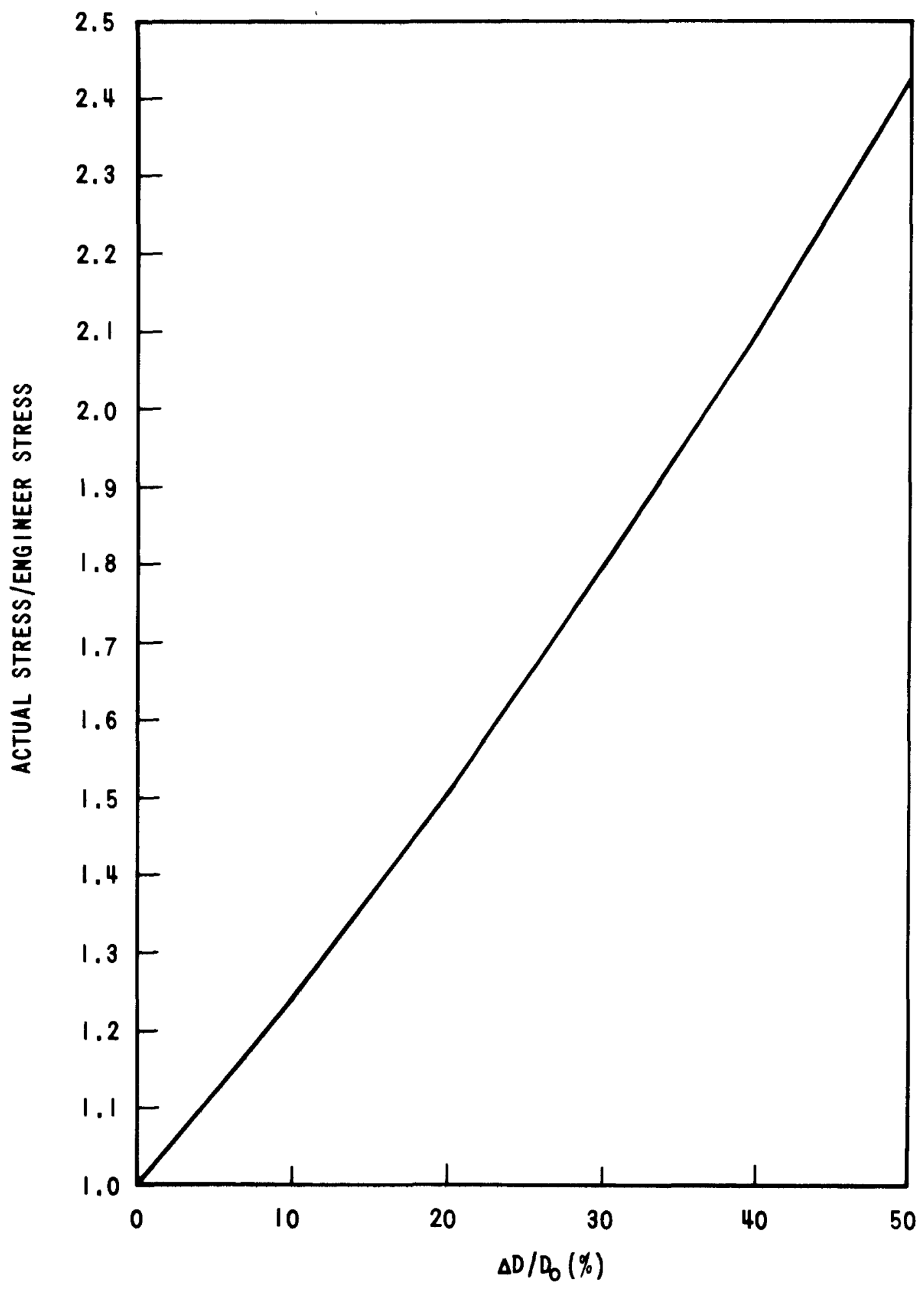

Figure 10. Ratio of Actual Hoop Stress to Engineering Hoop Stress Versus $\Delta D / D_{0}$ for Internally Pressurized 0.230 in. by 0.200 in. Tubing at Constant Pressure 
Superimposing on this hypothetical case some degree of non-uniformity in the initial wall thickness one would expect the thinner area of the circumference of the tube to strain at an ever increasing rate relative to the thicker area and perhaps fail by blowing out on the thin side. Continuing with this line of thinking consider the following implications:1) based on both the initial differential stress and the differential increase in stress as the test proceeds, a tube will fail at its weakest area; 2) it is this weakest area that determines, to a great extent, the rupture life of the specimen; but 3 ) it is the whole tube circumference, not just the weakest area, which determines the over all circumferential ductility, $\Delta D / D_{0}$.

Consider what would have been the result if the specimen shown in Figure 7 a would have experienced uniform wall thickness reduction throughout test to the maximum $\Delta t / t_{0}$ value observed rather than straining nonuniformly.

This particular specimen showed a maximum strain, measured by $\Delta t / t_{0}$ of about 42 percent at the 10 degree locations, and a minimum of about 15.5 percent $\Delta t / t_{0}$ at the 180 degree position. The \pm 90 degree positions were intermediate. Converting the $\Delta t / t_{0}$ value of 42 percent to an equivalent $\Delta \mathrm{D} / \mathrm{D}_{\mathrm{O}}$ value, assuming uniform wall thickness reduction, would give a ductility value of 65 percent $\Delta \mathrm{D} / \mathrm{D}_{\mathrm{o}}$ compared to the 35.3 percent $\Delta \mathrm{D} / \mathrm{D}_{\mathrm{O}}$ observed. In other words, as a result of the non-uniform wall thickness reduction, this specimen actually reached only a little more than half its potential ductility during test.

To give some credibility to the $\Delta t / t_{0}$ measurements used in this discussion, the $\Delta t / t_{0}$ measurements from the 180 , $+90,-90$ degree positions and the average value from the \pm 10 degree positions for this section were converted to equivalent $\Delta \mathrm{D} / \mathrm{D}_{\mathrm{O}}$ values, using a calculated equivalence curve based on area considerations. The estimated $\Delta \mathrm{D} / \mathrm{D}_{\mathrm{o}}$ from the mean of these four $\Delta t / t_{0}$ measurements was 33.4 percent $\Delta \mathrm{D} / \mathrm{D}_{\mathrm{O}}$ compared to 35.3 percent $\Delta \mathrm{D} / \mathrm{D}_{\mathrm{O}}$ independently measured by a comparitor. Thus, agreement is quite good, especially when one considers the number of independent measurements involved.

It appears from this line of thinking that to obtain the maximum hoop ductility from a given material, one should minimize those factors which promote non-uniform wall thinning.

There is another important implication with respect to size specifications. If one assumes that initial wall thickness variation is the primary cause for the observed non-uniform wall thickness reduction during test, then it also follows that one would expect a higher circumferential ductility, $\triangle \mathrm{D} / \mathrm{D}_{\mathrm{O}}$, from a tube having a uniform 0.014 inch wall than from one having a 0.014 inch wall in part of the circumference and a thicker wall in the ramainder, and that the hoop strength would be determined primarily by the 0.014 inch thickness in both cases.

It is recognized that real materials include other factors such as strain hardening which tends to offset the effects of initial wall thickness variation, and recovery and recrystallization which changes the stressstrain rate relation during test. Surface defects, if large enough, could also be an important variable. Differences in inherent ductility, such. as the difference between annealed and cold work tubing, also influence 
the relative results between the materials. For example, for an idealized uniform homogeneous tube (Figure 10), the greater the ductility $\Delta \mathrm{D} / \mathrm{D}_{\mathrm{O}}$, the greater the ratio of actual stress at rupture to the engineering stress (initial stress).

It appears from these results that local wall thickness measurements around the ruptured tube circumference combined with accurate pretest wall thickness measurements will aid in seperating mechanical effects and materials effects during test. The distinction is not apparent when only $\Delta D / D_{0}$ measurements are made. The $\Delta t / t_{0}$ type of measurement should also aid in evaluating the effects of natural and intentional defects on mechanical properties. Use of this approach is planned for defect evaluation program.

\subsubsection{Metallographic Evaluation}

Five of the nine transverse sections containing the ruptures from the previous $\Delta t / t_{0}$ analyses were further evaluated by metallographic evaluation. All specimens were rough polished with diamond abrasives and finished with a vibratory polisher. Modified glyceregia etch was used through out ( 3 parts glycerin, 3 parts $\mathrm{HCl}, 2$ parts $\mathrm{HNO}_{3}$ ). The etching time was varied to achieve the desired results. Figures 11 through 13 illustrate some of the observations.

The following results were obtained for Plug Drawn, Cold Worked Lot \# 42402 (Figure $11 \mathrm{a}$ and $11 \mathrm{~b}$ ):

1. Split type ruptures show grain shape distortion near the rupture, whereas the pin hole ruptures do not show distortion.

2. There is 1ittle circumferential structural difference around the post-test tubing except as described in (1) above.

3. There is no apparent structural variation from ID to OD across the tube wall.

4. There is marked difference in precipitate morphology between the short-term test and the long-term test. The short-term test specimens have fine precipitates, and long-term test specimens have both fine and coarse precipitates.

5. Heavy etching attacks some but not others of the large size class of precipitates in the long-term test specimen, indicating the possibility of more than one precipitate phase.

6. Rupture in the pin hole specimen initiated at the OD. Results from the split specimen are inconclusive.

7. The long term test specimen contains some cavities in the vicinity of the pin hole rupture. There are also some indications of cavities in the short term specimen but they may be of a different type. 


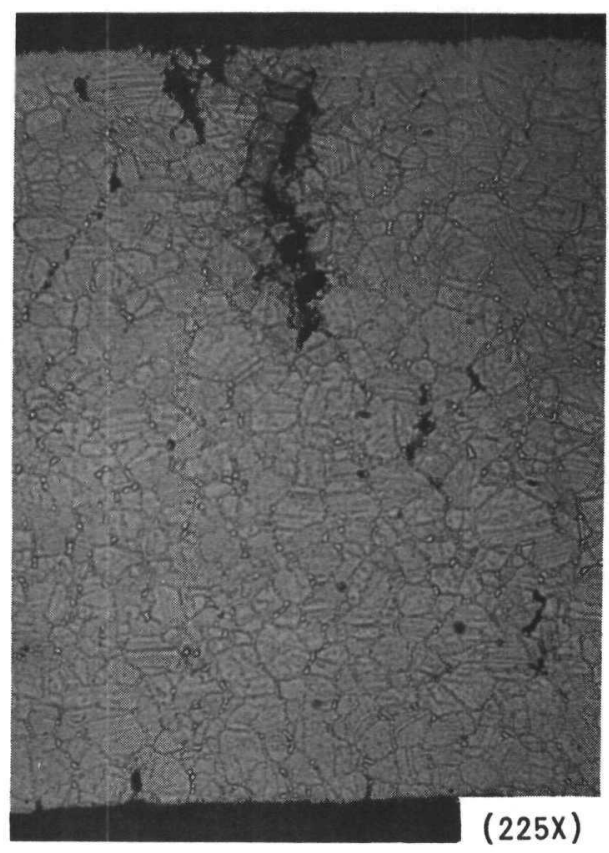

(1) $T_{R}=805 \mathrm{hr}, 15,000 \mathrm{psi}, 1314^{\circ} \mathrm{F}$, ETCHED

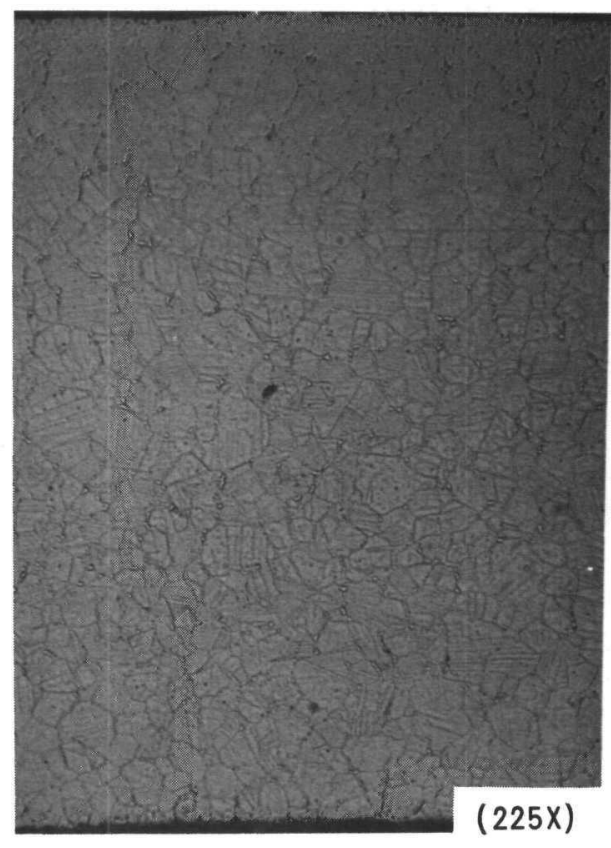

(3) $\mathrm{T}_{\mathrm{R}}=805 \mathrm{hr}, 15,000 \mathrm{psi}, 1314^{\circ} \mathrm{F}$, LIGHT ETCH

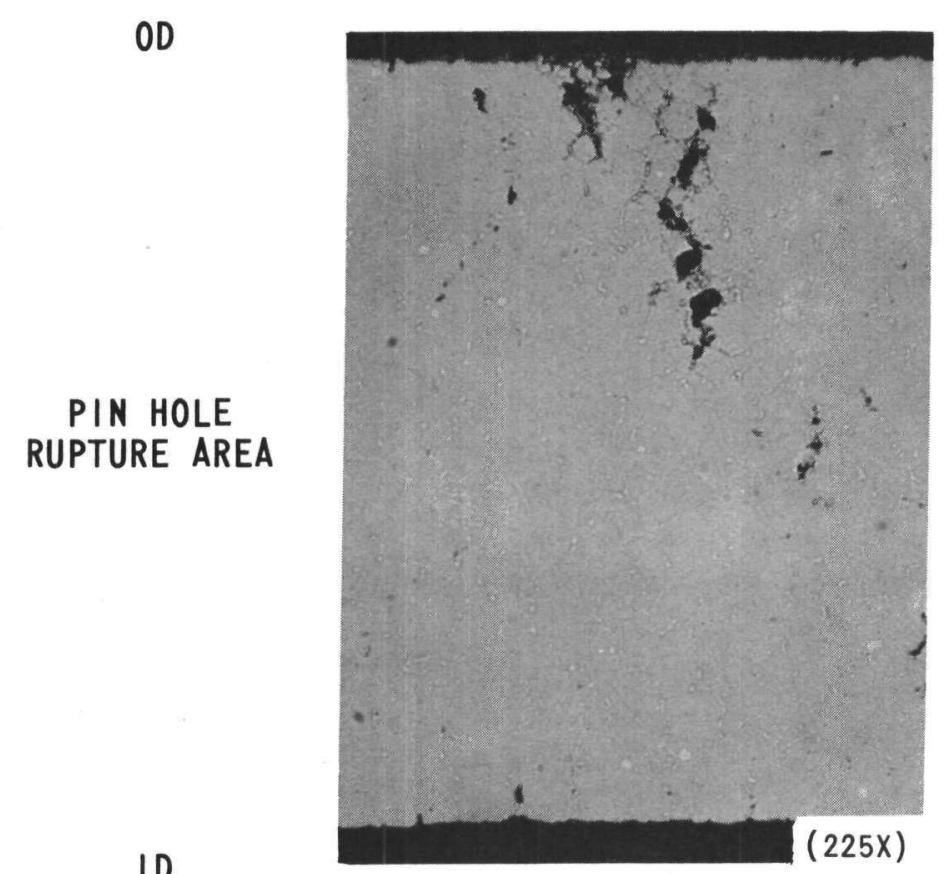

(2) $T_{R}=805 \mathrm{hr}, 15,000 \mathrm{psi}, 1314^{\circ} \mathrm{F}$, AS POLISHED

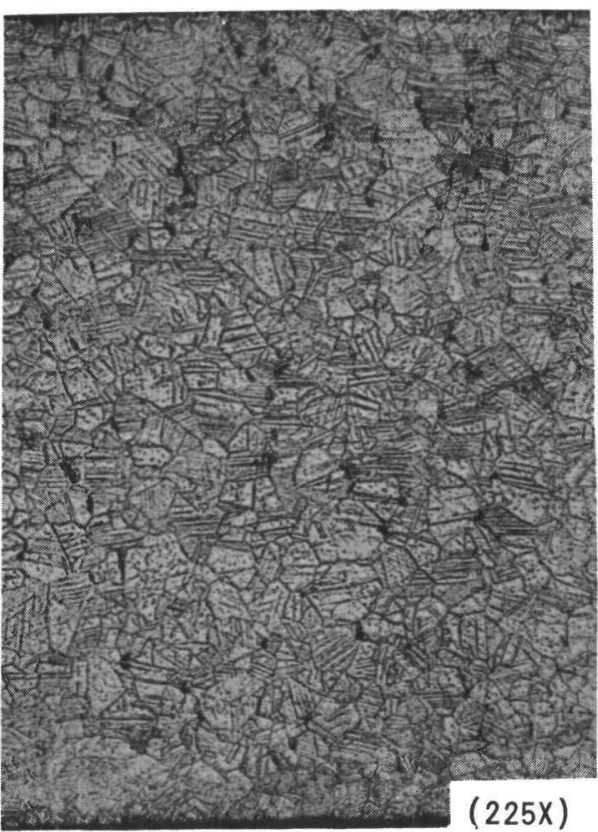

(4) $\mathrm{T}_{\mathrm{R}}=805 \mathrm{hr}, 15,000 \mathrm{psi}, 1314^{\circ} \mathrm{F}$, HEAVY ETCH

Figure 11a. Transverse Cross Sections of Post-Test Stress Rupture Specimens From Lot No. 42402 in the P1ug Drawn, 20 Percent Cold Worked Condition 


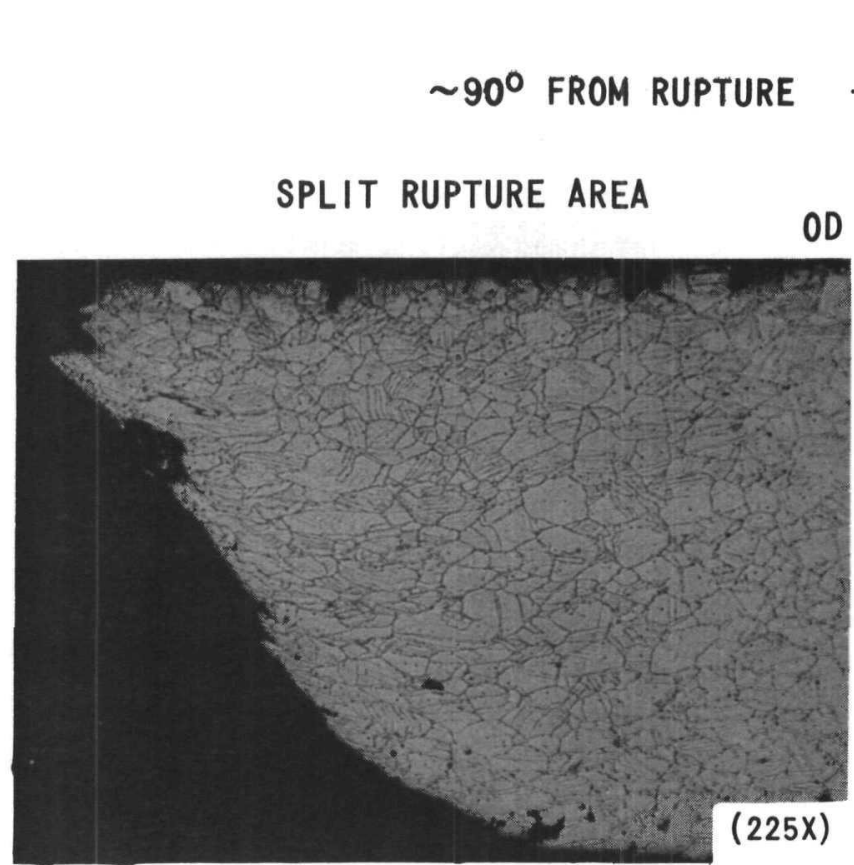

(1) $\mathrm{T}_{\mathrm{R}}=26.6 \mathrm{hr}, 30,000 \mathrm{psi}, 1313^{\circ} \mathrm{F}$

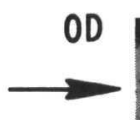

OD

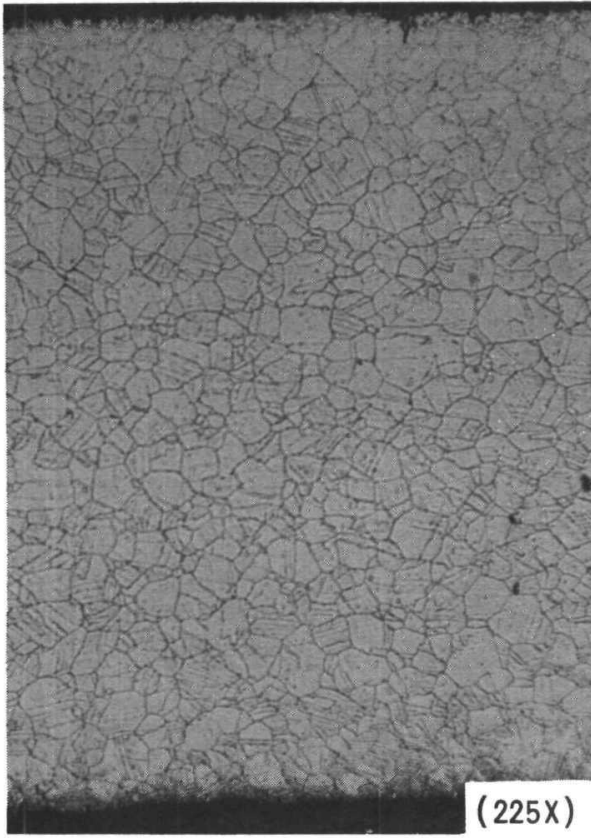

(2) $T_{R}=26.6 \mathrm{hr}, 30.000 \mathrm{psi}, 1313^{\circ} \mathrm{F}$ $1313^{\circ} \mathrm{F}$

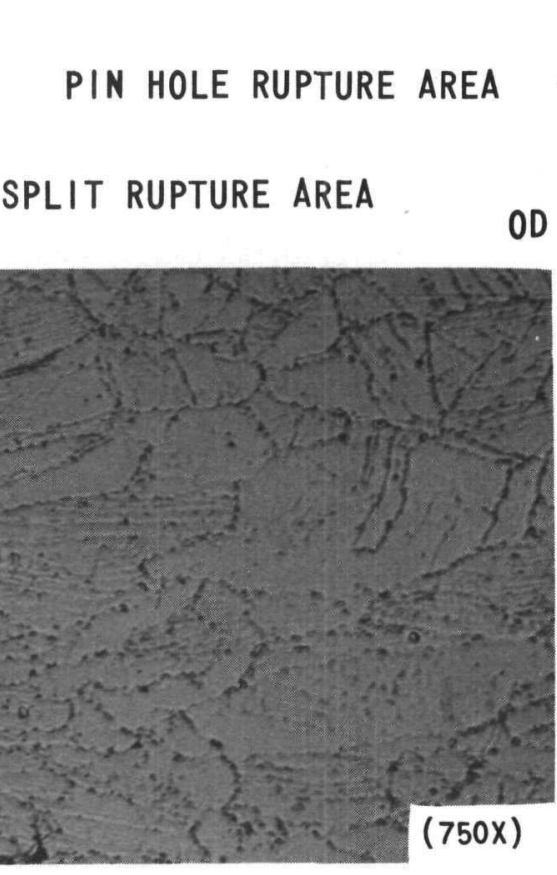

(3) $\mathrm{T}_{\mathrm{R}}=26.6 \mathrm{hr}, 30,000 \mathrm{psi}, 1313^{\circ} \mathrm{F}$

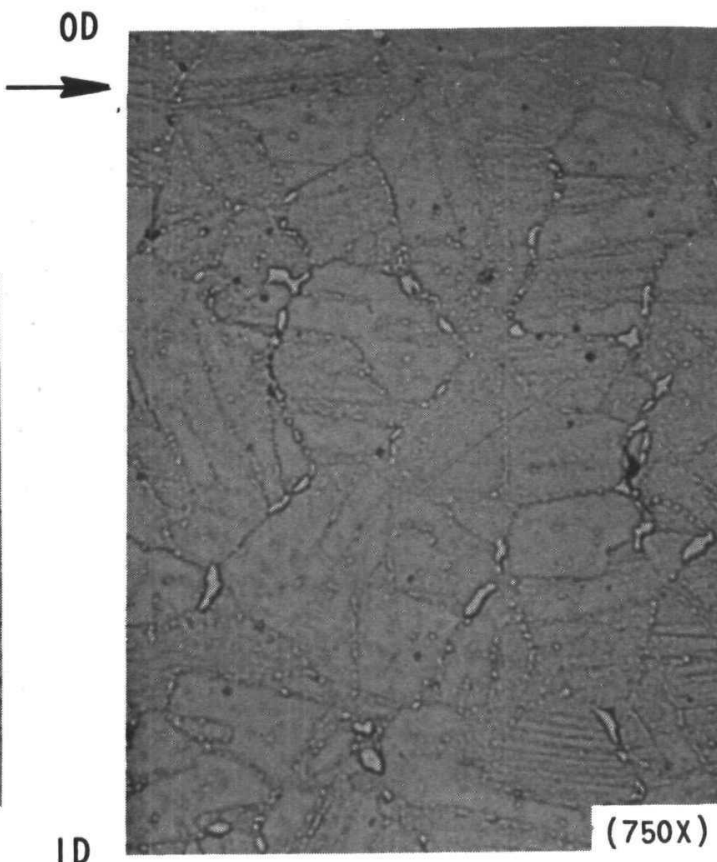

(4) $T_{R}=805 \mathrm{hr}, 15,000 \mathrm{psi}, 1314^{\circ} \mathrm{F}$

Figure 11b. Transverse Cross Sections of Post-Test Stress Rupture Specimens From Lot No. 42402 in the P1ug Drawn, 20 Percent Cold Worked Condition

3931-7 


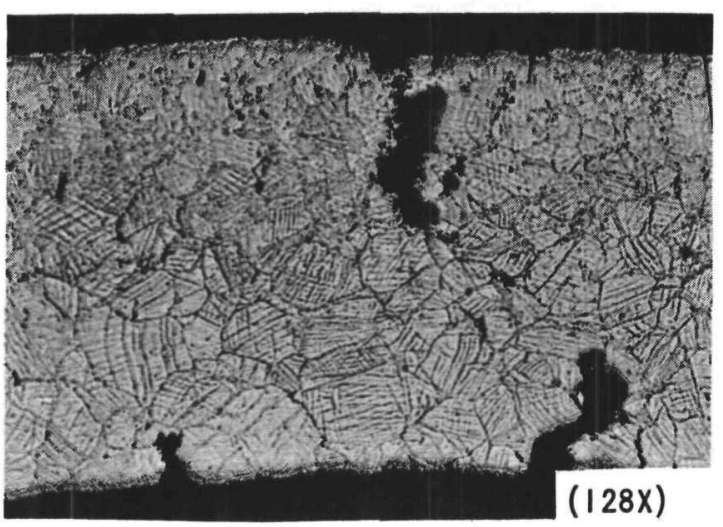

(1) $T_{R}=186 \mathrm{hr}, 20,000 \mathrm{psi}, 1316^{\circ} \mathrm{F}$, PIN HOLE RUPTURE AREA

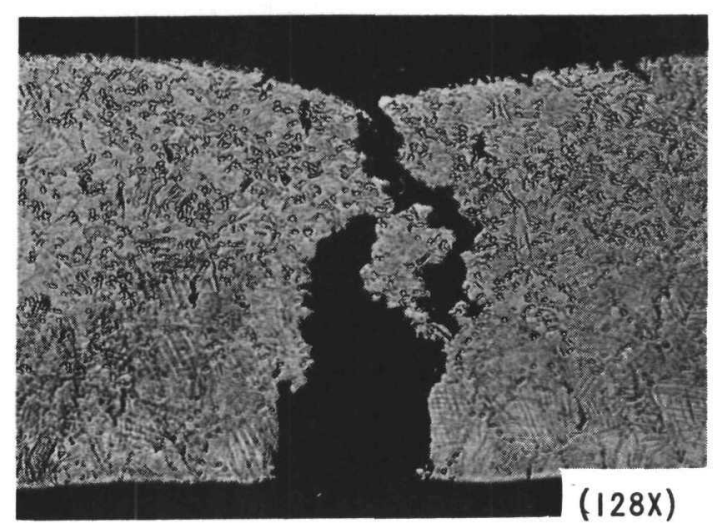

(2) $T_{R}=1493 \mathrm{hr}, 10,500 \mathrm{psi}, 1300^{\circ} \mathrm{F}$, PIN HOLE RUPTURE AREA

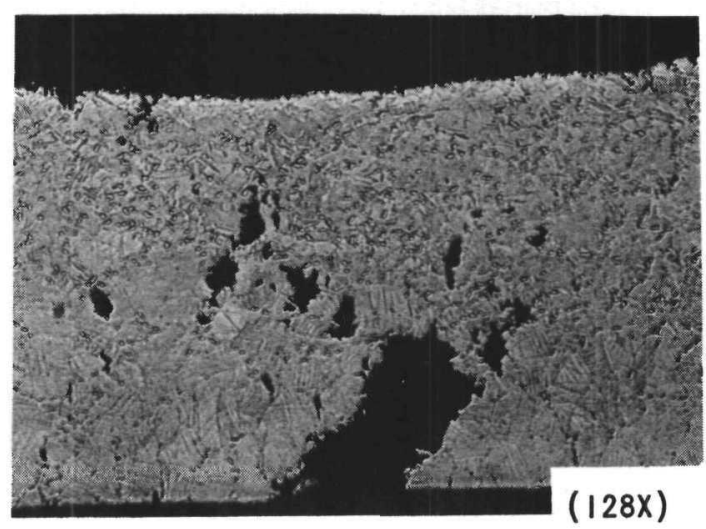

(3) $T_{R}=1493 \mathrm{hr}, 10,500 \mathrm{psi}, 1300^{\circ} \mathrm{F}$,

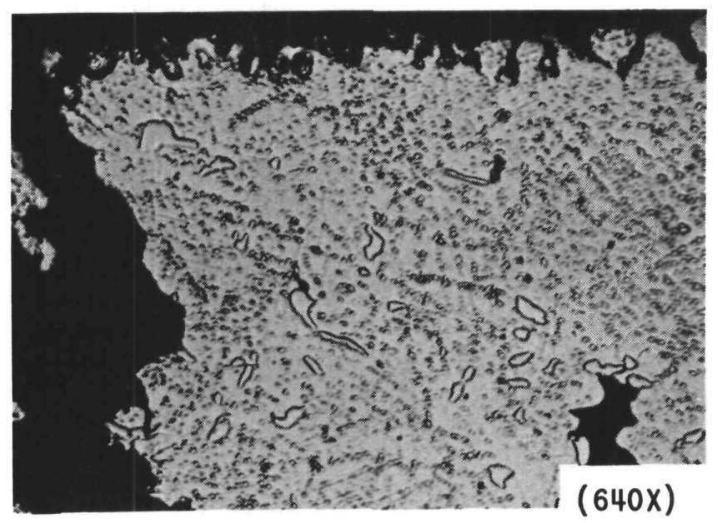

(4) $T_{R}=1493 \mathrm{hr}, 10,500 \mathrm{psi}, 1300^{\circ} \mathrm{F}$, PIN HOLE RUPTURE AREA

Figure 12. Transverse Cross Sections of Post-Test Stress Rupture Specimens From Lot No. 49193 in the Planetary Swaged, 20 Percent Cold Worked Condition 


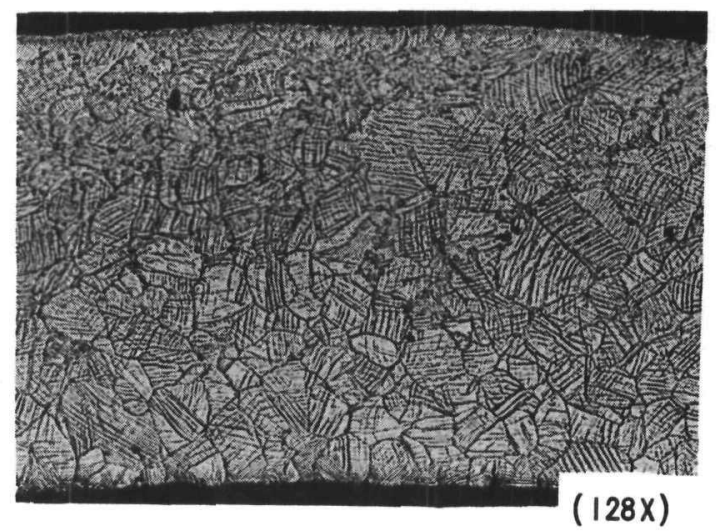

(I) $T_{R}=186 \mathrm{hr}, 20,000 \mathrm{psi}, 1316^{\circ} \mathrm{F}$

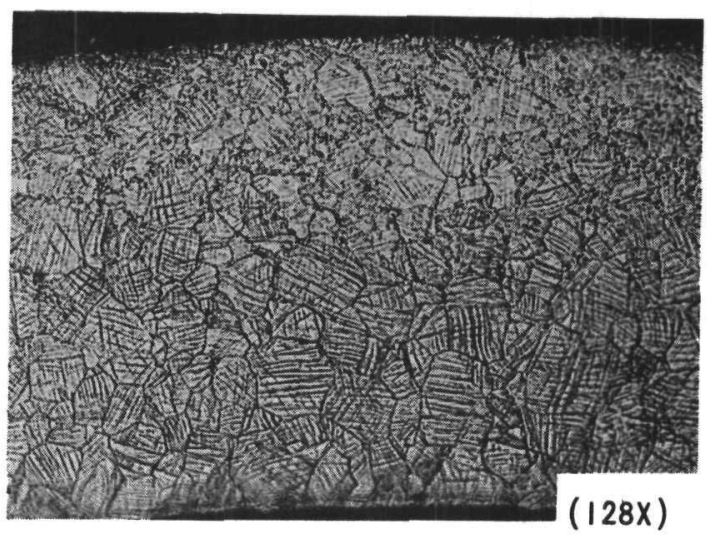

(2) $T_{R}=686 \mathrm{hr}, 16,000 \mathrm{psi}, 1293^{\circ} \mathrm{F}$

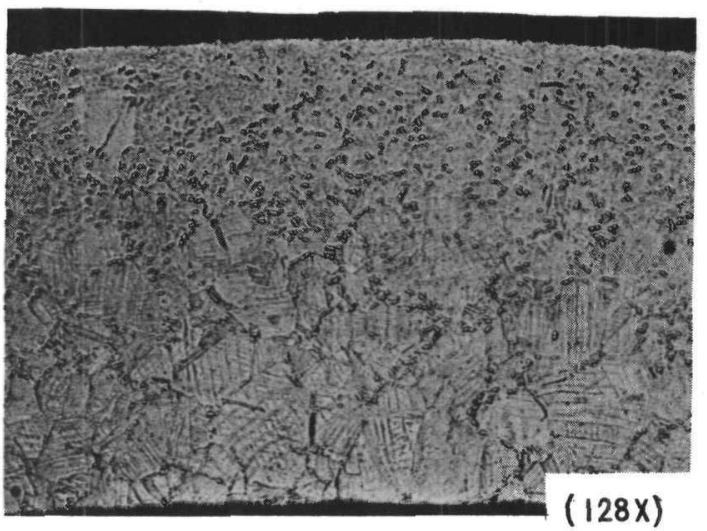

(3) $T_{R}=1493 \mathrm{hr}, 10,500 \mathrm{psi}, 1300^{\circ} \mathrm{F}$

Figure 13. Transverse Cross Sections of Post-Test Stress Rupture Specimen From Lot No. 49193 in the 20 Percent Cold Worked Condition Areas 90 Degrees From Rupture

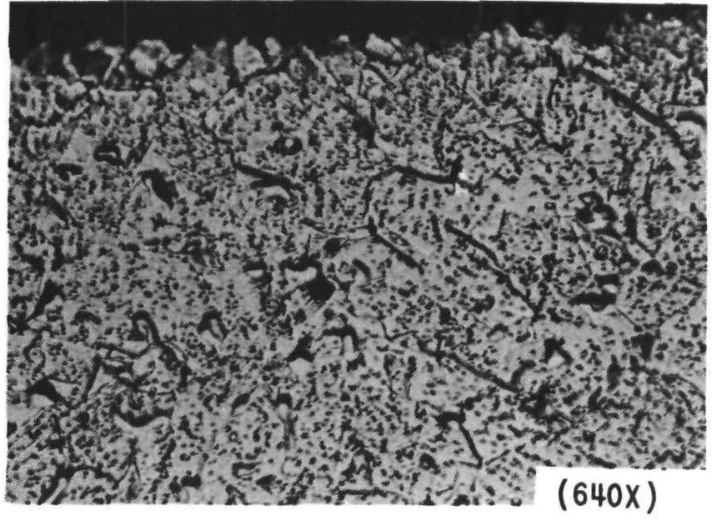

(4) $T_{R}=1493 \mathrm{hr}, 10,500 \mathrm{psi}, 1300^{\circ} \mathrm{F}$, HEAVY ETCH, NEAR OD

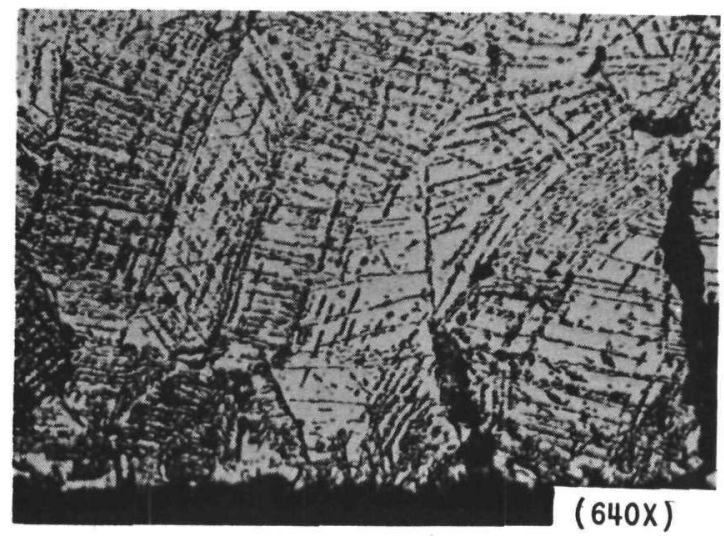

(5) $T_{R}=1493 \mathrm{hr}, 10,500 \mathrm{psi}, 1300^{\circ} \mathrm{F}$, HEAVY ETCH, NEAR ID 
The following results were obtained for Planetary Swaged Cold Worked Lot \# 49193 (Figures 12 and 13):

1. Three pin hole rupture specimens were examined. Ruptures initiated at the ID in all cases.

2. The structure near the OD of those specimens recyrstallized during the test.

3. The extent of recrystallization increased with time of test from the OD toward the ID.

4. There is a radial variation in the amount of the coarse precipitate in these specimens and the spatial distribution is correlated with the recrystallized annulus.

5. The precipitate observed in OD annulus of the planetary swaged specimens has a similar morphology to coarse precipitates in the long term specimen of plug drawn material.

\subsubsection{Discussion of Metallographic Results}

There are several important interpretations and implications relavent to these microstructural observations. The stress rupture plot for planetary swaged, cold worked tubing has a change in slope at a rupture time of about 300 hours at $1300^{\circ} \mathrm{F}$; this is approximately equal to the rupture conditions for the 186 -hour specimen tested at $1316^{\circ} \mathrm{F}$. Normalizing these test conditions for this specimen to $1300^{\circ} \mathrm{F}$, using the Chitty Duval "m" parameter, the equivalent rupture time would be 323 hours at $1300^{\circ} \mathrm{F}$ for the same stress. It is reasonable from the inftiation of recrystallization on the $O D$ of this specimen at the approximate break point in the stress rupture plot and the increase in the extent of recrystallization with increased test time, that recrystallization of the structure is the cause for the change in slope. This microstructural evaluation also suggests that there may be another change in slope in the stress rupture curve when recrystallization is complete.

Specimens have not yet been examined from plug drawn material tested at conditions beyond the break in that curve (about 900 hours at $1300^{\circ} \mathrm{F}$ ).

One of the significant differences reported previously [11] between the two lots of material (plug drawn and planetary swaged) is the degree of effective cold work from a metallurgical viewpoint in spite of the same nominal cold work based on percent area reduction during fabrication. It will be informative to determine if the plug drawn material with its lower degree of effective cold work and long rupture time before the break in the curve is also undergoing recrystallization after the change in slope of its curve.

Another significant difference observed between the plug drawn and the planetary swaged specimens examined is the initiation of the rupture on the OD of the plug drawn material and the ID of the planetary swaged 
tubing. llere again, specimens from different segments of their respective rupture plots have been compared. The recrystallization material on the on of the planetary swaged tubing would be expected to have greater ductility than the remainder of the tube wall. This would tend to cause the initiation of rupture to occur on the ID. More informative comparisons can be made when additional observations are made on the plug drawn material after the break in the curve.

Future planned observations include:

1. Check that the short-term tests for planetary swaged material from the flatter part of the stress rupture curve do not show recrystallization, as the present interpretation would predict.

2. Examine plug drawn material specimens from tests beyond 900 hours at $1300^{\circ} \mathrm{F}$, the break point in the curve, to determine if recrystallization is also the cause of the change in slope in this material and to look for the location of the initiation of rupture.

3. Identify the precipitates in these samples and attempt to assign their role in the stress rupture properties.

4. Examine the post-test rupture specimens from the annealed materials, particularly those specimens which exceed the cold worked materials in stress rupture life at the same stresses.

5. Evaluate quantitatively the void distribution in selected specimens. 


\section{LIST OF REFERENCES}

1. F. Garofalo, F. Von Gemmingen, and W. F. Domis, "The Creep Behavior of an Austenitic Stainless Steel as Effected by Carbides Precipitated on Dislocations," Trans. Am. Soc. Metals 54, pp. 430-444 (1961).

2. F. L. Becker, C. E. Fitch, and R. L. Richardson, "Ultrasonic Reflection and Transmission Factors for Materials with Attenuation," BN!NL-1283, (March 1970).

3. F. L. Becker and R. L. Trantow, "Nondestructive Evaluation of Cladding Cold Work and Grain Size," Trans. Amer. Nucl. Soc. 12, No. 2, p. 540, (1969).

4. F. L. Becker and R. L. Richardson, "Critical-Angle Reflectivity," J. Acoust. Soc. Amer. 45, No. 3, pp. 793-794, (1969).

5. F. L. Becker and R. L. Richardson, "U1trasonic Critical Angle Reflectivity," Research Techniques in Non-destructive Testing 1 , Academic Press, iN. Y.

6. F. L. Becker, "Phase Measurements of Reflected Ultrasonic Waves Near The Rayleigh Critical Angle," BNWL-SA-3188, (March 1970).

7. "Reactor Fuels and Materials Development Programs for Fuels and Materials Branch. Quarterly Progress Report, July-September 1969," BNWL-1223, (ivovember 1969).

8. C. V. Dodd and W. A. Simpson, "Measurement of Small Magnetic Permeability Changes by Eddy Current Techniques," presented at the American Society for Nondestructive Testing Fal1 Conference, October 19-22, 1970, Cleveland, Ohio.

9. "Fuels and Materials Development Program Quarterly Progress Report for Period Ending September 30, 1969," ORNL-4480, (February 1970).

10. Personal communication with C. J. Renken of ANL (6-29-70 and 9-23-70).

11. "Stainless Steel Cladding Development. Quarterly Progress Report for the Period Ending June 30, 1970," WARD-4135-12, (August 1970).

12. "Stainless Steel Cladding Development. Quarterly Progress Report for Period Ending March 31, 1970," WARD-4135-9, (April 1970). 
Division of Reactor Development and Technology U. S. Atomic Energy Commission

Washington, D. C. 20545

Attn: Director

Assistant Director, Engineering Standards

Assistant Director, Nuclear Safety

Assistant Director, Plant Engineering

Assistant Director, Program Analysis

Assistant Director, Project Management

Assistant Director, Reactor Engineering (2)

Assistant Director, Reactor Technology

Chief, Fuels and Materials Branch

Chief, Fuel Engineering Branch

Chief, Reactor Vessels Branch

Chief, Coolant Chemistry Branch

Chief, Core Design Branch

Assistant Director

Pacific Northwest Programs

U. S. Atomic Energy Commission

P. O. Box 550

Richland, Washington 99352

USAEC-RDT Site office

Argonne National Laboratory

Building 2

Argonne, Illinois 60439

USAEC-RDT Site office

P. C. Box 2108

Idaho Falls, Idaho 83401

USAEC-RDT Site office

P. O. Box 1446

Canoga Park, California 90304

USAEC-RDT Site office

310 DeGuigne Drive

Sunnyvale, California 94086

USAEC-RDT Site office

P. 0. Box 2325

San Diego, California 92112

USAEC-RDT Site Office

P. 0. Box 154

Madison, Pennsylvania 15663 


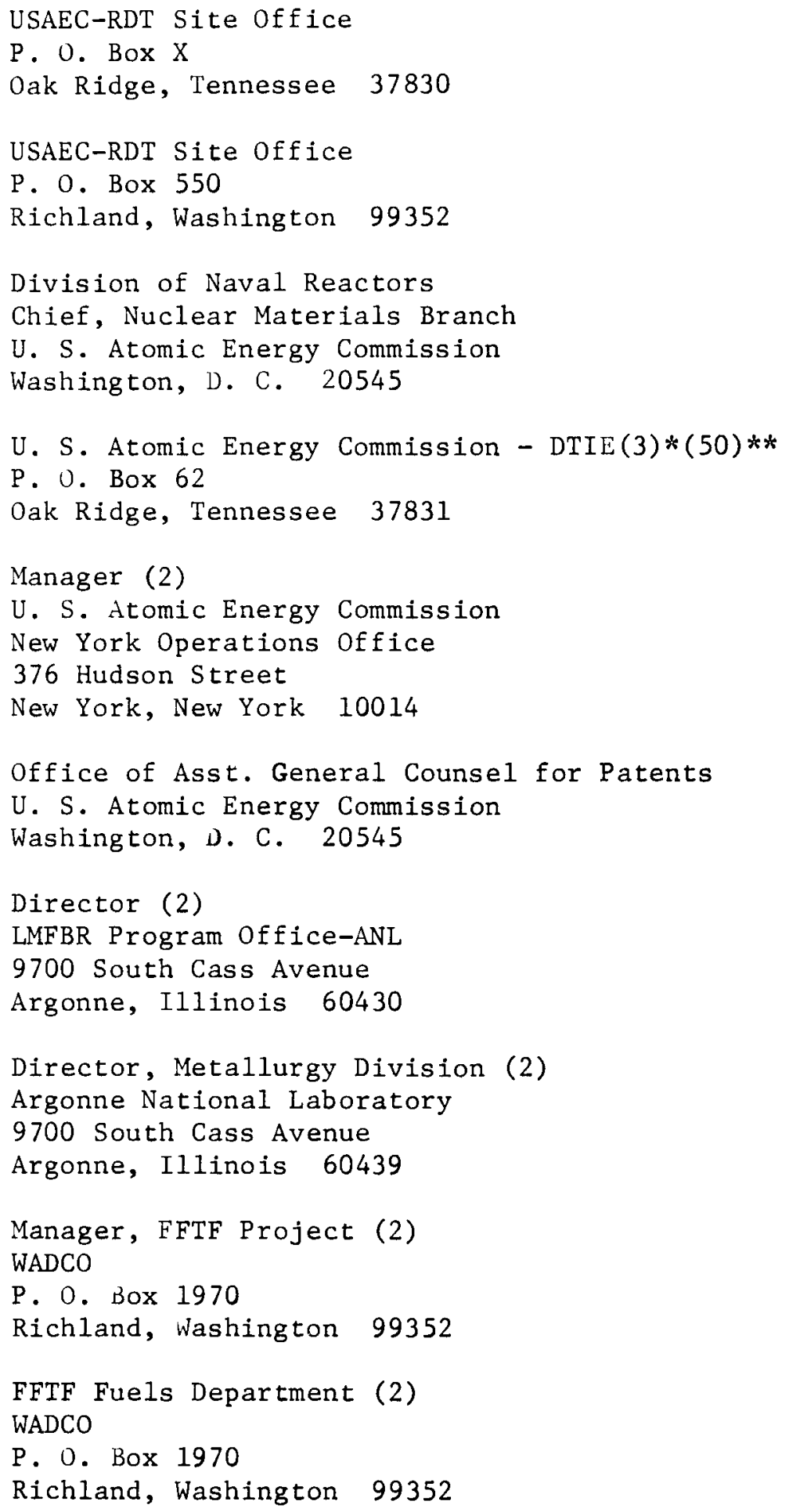

* submitted with transmittal form AEC-426

**submitted for transmittal to recipients under UKAEA/USAEC and EURATOM/USAEC Fast Breeder Information Exchange arrangements. 
Manager, Chemistry and Metallurgy Div.

Battelle Northwest Laboratory

P. O. Box 999

Richland, Washington 99352

Division Leader, Chemistry and Metallurgy Div. (CMB)

Los Alamos Scientific Laboratory

P. O. Box 1663

Los Alamos, iNew Mexico 87544

Director, Metallurgy and Materials Science Division

Brookhaven National Laboratory

Upton, New York 11973

Director, Metals and Ceramics Division (2)

Oak Ridge Nationa1 Laboratory

P. O. Box X

Oak Ridge, Tennessee 37820

Division Chief, $M \& S$ Division

NASA - Lewis Research Center

2100 Brook Park Road

Cleveland, Ohio 44135

Director

Atomics International

Liquid Metal Engineering Center

P. O. Box 309

Canoga Park, California 91305

Manager-Advanced Development Activity

General Electric Company

Knolls Atomic Power Laboratory

P. 0. Box 1072

Schenectady, New York 12301

General Manager

Westinghouse Electric Corporation

Bettis Atomic Power Laboratory

P. 0. Box 79

West Mifflin, Pennsylvania 15122

Director, LMFBR Technology Program

Atomics International

P. 0. Box 309

Canoga Park, California 91304

Associate Manager, Materials Engineering Dept.

Battelle Memorial Institute

Columbus, Ohio 43201 
Director, Nuclear Development Center

The Babcock and Wilcox Company

Atomic Energy Division

Lynchburg, Virginia 24501

Manager, Plutonium Chemistry and Ceramics Fuels Development

Nuclear Materials and Equipment Corporation

Leechburg, Pennsylvania 15656

Manager, Sodium Reactor Technology

General Electric Company

Breeder Reactor Development Operation

310 DeGuigne Drive

Sunnyvale, California 94086

Manager, Nuclear Laboratories

Combustion Engineering, Inc.

Nuclear Division

Prospect Hill Road

Windsor, Connecticut 06095

Laboratory Assistant Director

Gulf Energy \& Environmental Systems, Inc.

P. 0. Box 608

San Diego, California 92112

Manager, Research

United Nuclear Corporation

Research and Engineering Center

Grasslands Road

Elmsford, New York 10523

Head, Fuels and Materials

Atomic Power Development Associates

1911 First Street

Detroit, Michigan 48226

K-2 Group Leader

Reactor Division

Los Alamos Scientific Laboratory

P. O. Box 1663

Los Alamos, New Mexico 87544

Irradiations Coordinator

EBR-II Project

Argonne National Laboratory

P. O. Box 1096

Idaho Falls, Idaho 83401

Director

Vallecitos Nuclear Center

General Electric Company

P. O. Box 846

Pleasanton, California 94566 
Experiment Manager

EBR-II Project

Argonne National Laboratory

9700 South Cass Avenue

Argonne, Illinois 60430 